Journal of Language Education and Research

\author{
Research Article
}

\title{
Examination of Speaking Skills of 60-72 Month Old Children
}

\author{
Begümhan Yüksel ${ }^{*}$
}

\section{ARTICLE INFO}

Received 18.02.2021

Revised form 8.04.2021

Accepted 15.04.2021

Doi:10.31464/jlere.881497

\section{Keywords:}

language development

speaking skill

pronunciation

fluency

\begin{abstract}
The aim of the study is to determine the speaking skill levels of children between the ages of 60-72 months. The research group of the study consists of 60 children between 60-72 months in the city center of Antalya. Data were collected using the "Speaking Skills Assessment Scale". For this, the children were watched a short cartoon movie, and then they were asked to describe what they had watched in their own words. The data of the research were obtained by analyzing the conversations acquired from these interviews. Speeches were evaluated in terms of pronunciation, fluency and language competency. According to the findings, it was determined that the speaking skills of the participant children were at a medium level in terms of pronunciation and fluency, and a lower level in terms of language competency. According to the other results obtained from the research pronunciation skill level fluency and fluency level also predict language competency. While girls are more successful than boys in terms of their pronunciation, there is no difference between them in terms of fluency and language proficiency. In addition, the six-month age difference is not a variable that makes a difference in terms of pronunciation, fluency and language consistency. Based on these results, it is recommended to conduct studies in other age groups and with different tools.
\end{abstract}

\section{Acknowledgments}

Statement of Publication Ethics

This study was conducted in accordance with publication ethical principles. Before the data was collected, permission number 75 was obtained from the Ethics Committee by the Social and Human Sciences Scientific Research and Publication Ethics Committee on 01.03.2021

\section{Authors' Contribution Rate}

Conflict of Interest

There is no conflict of interest in this study.

\footnotetext{
* Dr., ORCID ID: https://orcid.org/0000-0002-0869-9157, Akdeniz University, Faculty of Education, begumhanyuksel@gmail.com
} 


\section{Introduction}

One of the important indicators of the level of development in children is speaking skill. Growing up in a social environment, children interact with other people through speech. Speaking skill is a type of skill that allows children to reflect their individual quality defined by cognitive and linguistic development while being the primary means of participating in social contexts. Children use language to organize such experiences (Alexander, 2006; Mercer \& Littleton, 2007; Wells, 1999). Through language, the basic features of various contexts are understood and also through speaking, which is a different skill dimension of language participation occurs to these contexts.

Speaking also underlines literacy and other learning. Points such as sound awareness, effective vocabulary, and storytelling success are important signs of future reading comprehension and decoding skills (Dickinson \& Porche, 2010; Resnick \& Snow, 2009). Word choices made by children in verbal interactions with others, their pronunciation styles, and the linguistic connections they create while performing are important signs of language acquisition level and social learning. For this reason, determining the speech characteristics at a certain point in the development process of children is the starting point of many teaching fields, studies and research.

Spoken language also supports future reading and writing learning. Success in reading and writing skills emerges as an extension of speaking and listening learned in preschool period. Therefore, children who are inadequate in terms of speaking skills in the preschool period may not be able to keep up with other children in the following years (Biemiller, 2006; Dougherty, 2014; Scarborough, 2001). In order to avoid this situation, it is necessary to determine the speech characteristics of children and to eliminate some deficiencies in the preschool period.

\section{Literature Review}

It is known that children who develop speaking skills in early childhood are also successful in skills such as initiating and maintaining social relationships, interpreting new information they have acquired, and conveying their feelings and thoughts. Speaking increases the self-confidence of children by providing socialization (Baş, 2002) Considering that the key to successful communication is effective use of sound and beautiful and understandable speech (Kurudayığlu, 2003), it is possible to say that speaking is the basis for children to communicate with the individuals around them. Children's speaking skills enable them to be successful both in social life and school life (Demir, 2010). Considering that the general purpose of speaking lessons in educational institutions is to provide students with the ability to express their emotions and thoughts in a correct and effective manner in accordance with the language rules (Özbay, 2005), the speaking skills of children in early childhood should be supported systematically.

Language is a system made up of many components (Fromkin \& Rodman, 1983). Communicating using a multicomponent system requires a certain level of competence in each relevant component. The primary components of the language are gathered in sound, 
form, syntax, meaning and usage points. Extra-Linguistic information that affects the use of language can also be added to these items. With each use of language skills, including speaking, the components of language begin to operate on their own plane. The speaking individual operates the elements specified in each plane of the language in harmony with each other.

One of the important components of linguistic knowledge is to have knowledge of the sounds used. Individuals who use the language should know the sounds of that language and be able to apply the rules of combining sounds during speech. The evaluation of children's speaking skills in terms of sound can be made according to the vocal awareness they have. Speech awareness requires to know how the sounds in language are combined and what kind of distribution they show. Speech awareness also significantly influences later reading skills (Bradley \& Bryant, 1978; Goswami \& Bryant, 1990; Lundberg et al., 1988). Awareness syllables for sounds that form the basis of language skills are handled in three points covering the sounds in syllables and phonemic elements. (Treiman \& Zukowski, 1991; Stanovich, 1992; Hoien vd., 1995). Each of these points indicates the sounds children should produce in a way that the listener perceives while speaking.

The sounds of the language are performed to create words and sentence structures that correspond to certain meanings. Linguistic meaning dimension is another important component of speaking skill. The basic semantic units in language are words (Fromkin et al., 2011). Adequate reflection of children's speaking skills requires having certain words of the language. Children learn which word is associated with which meaning from the environment in which they live. Learned words are classified in the mind and their usage takes place over word classes. For example, the word vehicle is a class, and it means automobile, bus, train, etc. contains sub-meanings (Resnick \& Snow, 2009). Children choose these words according to their meanings and use them in grammatical structures. Most of the studies on children's vocabulary focus mostly on words based on naming various pictures in relation to the receptive language (Rowe et al., 2012; Vagh et al., 2009). Perfetti (2009) draws attention to the difference in vocabulary knowledge in children. When children start school, there is a rapid development in their vocabulary. Speaking of children with large vocabulary happens more effectively.

Words are one of the morphological units of language. Morphological unit includes words as well as the suffixes. Knowledge of words and their meanings also necessitates morphological knowledge to understand and acquire their inflected forms in use. Plural, time, negativity, etc. suffixes cause words to appear to children in different ways. It can be thought that children who have knowledge of morphemes that meet the smallest units that convey meaning in a language, have knowledge of the semantic and functional qualities that suffixes bring to words as well as knowledge of the roots and bodies of the words. The development of speaking skill, which is a dimension of language acquisition, requires using different forms of words. Language users should have knowledge of the number of words as well as their depth (Kieffer \& Lesaux, 2012). Depth is the equivalent of knowledge of different forms of words. 
The fact that children have encountered words many times in their development is extremely important in terms of both learning and keeping them in their memories (Biemiller \& Boote, 2006; Coyne et al., 2007; Silverman, 2007). Children who show sufficient development in words reflect these in their speech. Children's vocabulary varies significantly starting from pre-school period. Preschool period is critical in determining these differences (Biemiller \& Boote, 2006; Hirsch, 2006). Studies have shown that preschool teachers do not use adequate strategies to improve children's vocabulary (Dickinson et al., 2008; Van Kleeck, 2008). Whereas children who gain a good vocabulary with the right methods can also improve their speaking skills and have a more successful learning life in the following periods.

Another essential element of language and speech is syntax. Syntactic information is an implicit type of information about how to combine words. Differential units are combined with certain rules through syntax (Fromkin et al., 2011). Implicit syntactic rule knowledge guides individuals on how to combine words. In other saying, words that are not combined according to these rules cannot meet a certain meaning. Therefore, syntactic structures require using words in association with each other. Children with knowledge of these rules can make well-structured sentences. Thus, their speech becomes more understandable.

In addition to the components that make up the inner workings of the language, there is also a dimension related to its usage. Language is always used for a purpose, based on the conditions of the context. Individuals by using language fulfill purposes such as explaining, giving information, asking questions, greetings, etc. Knowledge of the use of language in different contexts corresponds to its pragmatic dimension. Pragmatics is the name of the discipline that considers language as a means of communication to achieve certain social goals (Owens, 2012). When individuals with a pragmatic knowledge of language use it in communication with others, they can find and use appropriate words and structures based on the relevant social context. Structures suitable for the speaker's purpose like whether the listener is identified or not, his/her age or status during the conversation; whether the context in which the communication takes place is formal or informal, are obtained and used through pragmatic knowledge. Children's pragmatic knowledge directly affects their speech.

When the literature is examined, there are not many studies that examine the speech characteristics of preschool children in a broad perspective. However, there are some studies that examine children's general language skills or a specific point in the language. For example, Tural (1977) conducted a study examining whether the vocabulary of children between the ages of 4 and 6 differs according to various variables. While Anlar (1983) evaluated the language development of children up to the age of 6 in terms of gender and parental education level using the Denver Developmental Screening Test, Erkan (1990) examined the linguistic structures used by 4-5-year-old children and conducted a study focusing on the number and type of words. Öztürk (1995) examined children's receptive and expressive language development using the Peabody DrawingWord Test, and Dictionary and Language Test and Taner (2003) also investigated children's language development according to gender with the Peabody Drawing-Word 
Test. Besides, Koçak and Dereli (2005) investigated the expressive language levels of children between the ages of 4-6 and İpek (2006) also examined the vocabulary of children with the same test. Since many of these studies use the Peabody Drawing-Word Test, which focuses the word, it is seen that the studies are one-dimensional in terms of speaking skill. It is thought that there is a need for studies that examine the speaking skills of children in Turkish in a wider perspective. With this understanding, the following questions were searched in this study:

1. How do children's speaking skills display in sub-dimensions of pronunciation, fluency, content and language use?

2. To what extent does the level of pronunciation skills exhibited by children during speaking predicts their fluency?

3. To what extent does the fluency level exhibited by children during speaking predict the language competence and content dimension?

4. Do children's speaking skill levels differ by gender?

5. Do children's speaking skill levels differ by age?

\section{Method}

This study, which aims to determine the features seen in children's speech with the main lines, is a study in correlational scanning model. In the researches in the scanning model, is described as a situation that exists in the past or present (Karasar, 2000).

\section{Participants}

Participants of the study were 60 preschool children between $60-72$ months in the city center of Antalya. Participants were created using the convenience sampling method, which is one of the non-probable sampling methods. In the convenience sampling method, a sample is created starting from the most accessible respondents until a group of the required size is reached, or the most accessible and a situation that will provide maximum saving is studied. (Büyüköztürk et al., 2008).

Of the participants, $46.7 \%(\mathrm{n}=28)$ were boys and $53.3 \%(\mathrm{n}=32)$ were girls, $65.0 \%(\mathrm{n}=39)$ were $60-66$ months old, while $35.0 \%(\mathrm{n}=21)$ of them were between 67 and 72 months old. The reason why the participants are chosen from the age range of 6072 months (5 years) is that they are thought to have reached a certain level of speaking skills. In the literature, it is stated that children learn the language system around the age of three (Lust, 2006; O'Grady 2008). Children who reach the age of 4-5 begin to communicate in certain contexts with the language system they have acquired. Their vocabulary grows and they try to use more complex syntactic structures. The reason why the participants between 60-72 months are treated in two separate groups as 60-66 and 6772 is that the language development of children in preschool period is faster than ever in human life (Hoff, 2009; Kirjavainen et al., 2009).

Information about the demographic characteristics of the participants is presented in Table 1 below. 
Table 1. Demographic Information of the Participants

\begin{tabular}{llcc}
\hline & & Number of people & $\%$ \\
\hline Gender & Boy & 28 & 46.7 \\
& Girl & 32 & 53.3 \\
& Total & 60 & 100.0 \\
\hline Age (month) & $60-66$ & 39 & 65.0 \\
& $67-72$ & 21 & 35.0 \\
& Total & 60 & 100.0 \\
\hline
\end{tabular}

\section{Data collection tool}

The Personal Information Form created by the researcher was used to collect the demographic information of the participant children in the collection of the research data. The second tool used in the study is the Speaking Skills Assessment Scale (SSAS) developed by Bozkurt and Arıca-Akkök (2019). This scale is designed in a way that it allows to identify the weaknesses and strengths of a particular speaker. Each dimension can be used separately in the scale consisting of pronunciation, fluency, language competence and interaction / presentation dimensions. While the first three of the dimensions in the scale were designed as rubric scoring, the interaction / presentation dimension was created as a rubric observation form due to statistical processes. Items in the scale were graded with the terms weak, improvable, adequate and competent. CVI calculation of the items was made by consulting expert opinions; CVI calculation for all of the items in the dimensions of pronunciation, fluency and language competence was determined as 1.0. When looking at the items in the interaction / presentation dimension, it is seen that only two items have a CVI value of 0.8 and the other items have a value of 1.0. Therefore, this scale is a highly reliable scale in evaluating speaking skills. In this study, only the pronunciation, fluency, and language competence-content dimensions of the scale were used.

\section{Data collection and analysis}

Before the data was collected, permission number 75 was obtained from the Ethics Committee by the Social and Human Sciences Scientific Research and Publication Ethics Committee on 01.03.2021. In order to evaluate the speaking skills of the children participating in the study, a short cartoon movie was watched and asked to explain what they saw in this film. Audio and video recordings of children's expressions were taken based on the permissions received. The recordings were evaluated by two experts using the Speaking Skills Assessment Scale. As a result of the evaluations, the percentage of agreement between the experts was examined and as a result of the calculation, it was determined that the agreement was .91. 
The data collected from the participants were obtained in a single session. The speeches were evaluated and scored in terms of the items in the scale and the scores were transferred to the statistics program. The techniques to be used in the statistics program were determined according to the nature of the research questions. Before analyzing, the distribution of the data was examined. For this, the total score that the participants got from the sub-dimensions of the scale was calculated, then Skewness and Kurtosis values related to the distribution of these scores, central tendency measures and the result of the Shapiro Wilk test were examined. Skewness and Kurtosis values were found to be between +1.5 and -1.5 and the distribution was accepted as normal (Tabachnick \& Fidell, 2013). In the Shapiro Wilk test, $\mathrm{p}>.05$ inequality was provided. This result showed that the distribution was normal.

Consequently, it was determined that the scores obtained from the SSAS have a normal distribution. For this reason, T Test was applied for Independent Groups in the analyses for the difference of the scores from the SSAS according to gender and age. Simple linear regression analysis was used to determine the level of predicting the Fluency sub-dimension of the Pronunciation sub-dimension of the SSAS and the language competence and content sub-dimension of the SSAS Fluency sub-dimension.

\section{Findings}

In the first question of the study, it was aimed to determine the level of children's speaking skill levels in sub-dimensions of pronunciation, fluency, language competence and content. The results of the analysis made for this are shown in Table 2.

Table 2. Speaking Skills Assessment Scale Average Scores Obtained from The Sub-Dimensions of Pronunciation, Fluency and Language Competence-Content

\begin{tabular}{|c|c|c|c|c|c|}
\hline & & Dimensions & Items & $\overline{\mathrm{x}}$ & SS \\
\hline \multirow{7}{*}{\multicolumn{2}{|c|}{ 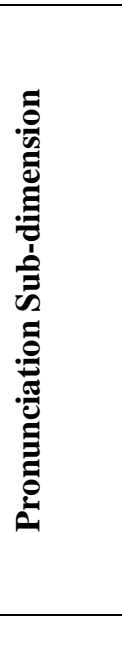 }} & Breathing / & 1.Ability to control breathing while speaking & 1.58 & .530 \\
\hline & & Posture & 2. Ability to speak in the correct posture & 1.68 & .537 \\
\hline & & Articulation & $\begin{array}{l}\text { 3. To be able to make speech sounds accurately and } \\
\text { completely }\end{array}$ & 2.37 & .843 \\
\hline & & Voice Intensity & $\begin{array}{l}\text { 4. The ability to continue the conversation with an audible } \\
\text { voice }\end{array}$ & 2.92 & .696 \\
\hline & & $\begin{array}{l}\text { Prosodic } \\
\text { features }\end{array}$ & $\begin{array}{l}\text { 5. To be able to use effectively all the features that affect } \\
\text { meaning such as emphasis, tone, melody. }\end{array}$ & 2.00 & .611 \\
\hline & & Standardization & $\begin{array}{l}\text { 6. Ability to speak within wide code possibilities by using } \\
\text { standard language. }\end{array}$ & 3.02 & .291 \\
\hline & & & Pronunciation Sub-dimension General & 2.26 & .333 \\
\hline \multirow{2}{*}{\multicolumn{2}{|c|}{ 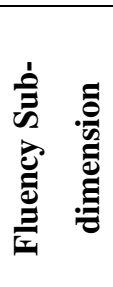 }} & $\begin{array}{l}\text { Pausing } \\
\text { (Filled sounds } \\
\text { or words) }\end{array}$ & $\begin{array}{l}\text { 7. Pauses in speech that are rarely seen below the acceptable } \\
\text { duration: The speech can be perceived as a whole and } \\
\text { progresses fluently. }\end{array}$ & 2.38 & .691 \\
\hline & & Recurrence & $\begin{array}{l}\text { 8. Avoiding word and sentence repetitions in his/her speech: } \\
\text { The progress of the speech fluently }\end{array}$ & 2.37 & .663 \\
\hline
\end{tabular}




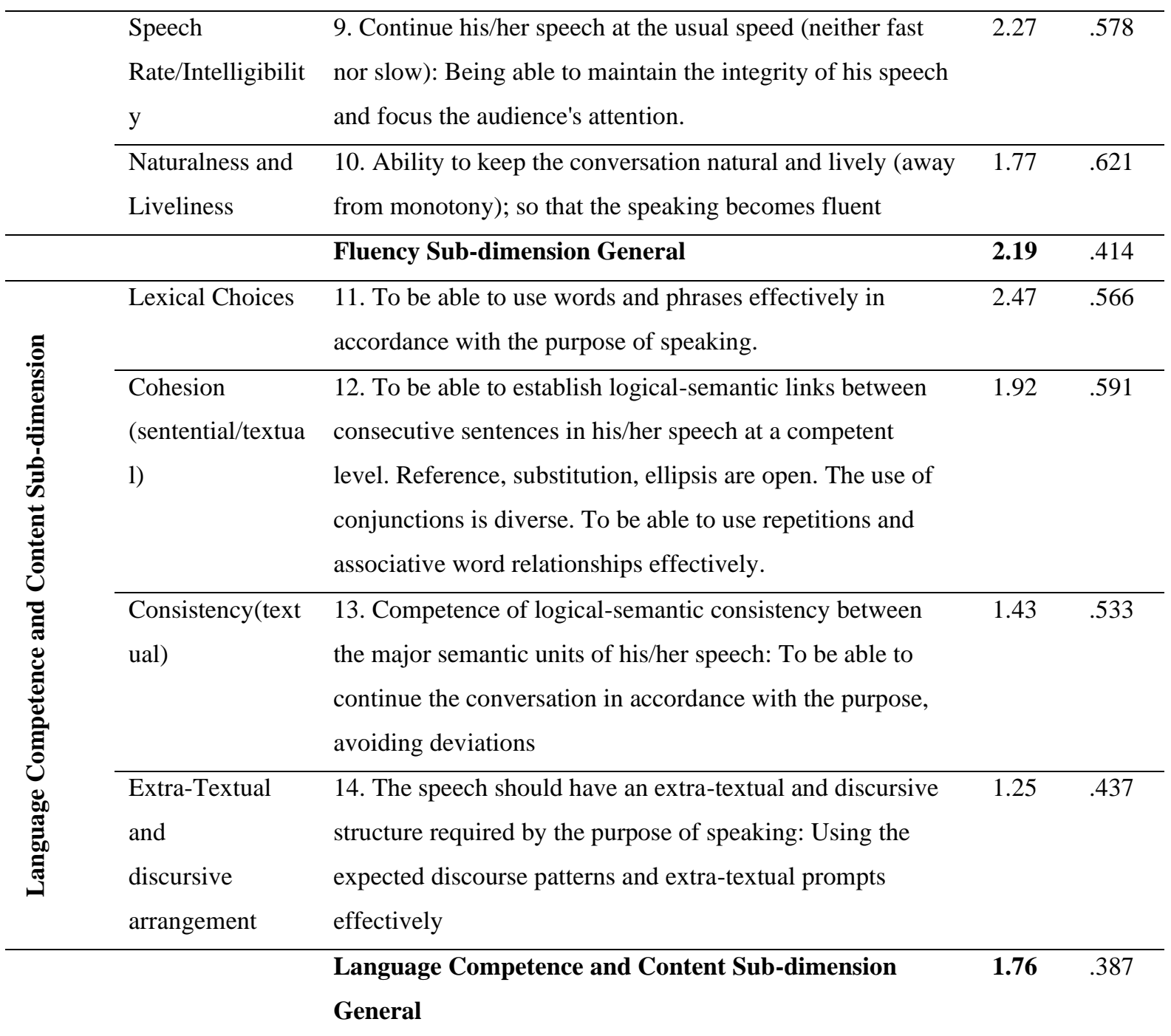

As seen in Table 2, participating children reached an average of 2.26 in the pronunciation sub-dimension, 2.19 in the fluency sub-dimension, and 1.76 in the language competence-content sub-dimension. Considering that the items in the Speaking Skills Assessment Scale received at least 1 and a maximum of 4 points, it can be said that children are slightly above the middle in terms of pronunciation and fluency, but slightly below the middle in language competence-content dimensions. In addition, the levels of children on the basis of items are reflected in the table above.

In the second question of the study, it was aimed to determine to what extent children's pronunciation skill levels predicted their fluency. The results of the regression analysis applied for this point are shown in Table 3.

Table 3. The Result of Simple Linear Regression Analysis for the Predictive Level of the Fluency Sub-Dimension of the Speaking Sub-Dimension of the Speaking Skills Rating Scale

\begin{tabular}{llllll}
\hline Fluency & $\mathrm{B}$ & $\mathrm{Sh}$ & $\beta$ & $\mathrm{t}$ & $\mathrm{p}$ \\
\hline Stable & .815 & .324 & & 2.513 & .015 \\
Pronunciation & .611 & .142 & .492 & 4.302 & .000
\end{tabular}

$\mathrm{n}=60, \mathrm{R}=.49, \mathrm{R}^{2}=.24, \mathrm{~F}=18.50, \mathrm{p}<0.01$ 
According to the results of the simple linear regression analysis, it was seen that the skill level of the pronunciation sub-dimension, one of the sub-dimensions of the speaking skill rating scale, significantly and positively predicted the skill level of the fluency subdimension $\left(\mathrm{R}=.49, \mathrm{R}^{2}=.24, \mathrm{~F}=18.50, \mathrm{p}<0.01\right)$. As stated in the table, the skill level related to the pronunciation sub-dimension explains $24 \%$ of the total variance in the skill level regarding the fluency sub-dimension.

In the third question of the study, it was aimed to determine to what extent children's fluency levels predicted their language competence and content levels. The results of the regression analysis applied for this question are presented in Table 4.

Table 4. The Result of Simple Linear Regression Analysis on the Predictive Level of the Fluency Sub-Dimension of the Speaking Skills Rating Scale's Language Competence and Content SubDimension

\begin{tabular}{llllll}
\hline $\begin{array}{l}\text { Language } \\
\text { competence and } \\
\text { content }\end{array}$ & $\mathrm{B}$ & $\mathrm{Sh}$ & $\mathrm{t}$ & $\mathrm{p}$ \\
\hline Stable & .631 & .228 & & & \\
Fluency & .517 & .102 & .553 & 5.057 & .008 \\
\hline $\mathrm{n}=60, \mathrm{R}=.55, \mathrm{R}^{2}=.30, \mathrm{~F}=25.57, \mathrm{p}<0.01$ & & & & \\
\hline
\end{tabular}

According to the results of the simple linear regression analysis, it was seen that the skill level of the fluency sub-dimension, one of the sub-dimensions of the speaking skill rating scale, significantly and positively predicted the skill level of the language competence and content sub-dimension $\left(\mathrm{R}=.55, \mathrm{R}^{2}=.30, \mathrm{~F}=25.57, \mathrm{p}<0.01\right)$. The table shows that skill level related to fluency sub-dimension explains $30 \%$ of the total variance in skill level related to language competence and content sub-dimension.

In the fourth question of the study, it was aimed to determine whether the children's speech levels differ according to gender. The result of the $t$ test applied for this point is given in Table 5.

Table 5. $T$ Test Result for the Difference of the Scores Obtained from the Speaking Skills Rating Scale According to Gender

\begin{tabular}{lllllll} 
& Gender & $\mathrm{N}$ & Ort. & SS & $\mathrm{t}$ & $\mathrm{p}$ \\
\hline Pronunciation Sub- & Boy & 28 & 2.1548 & .37386 & -2.399 & $\mathbf{. 0 2 0}$ \\
dimension & Girl & 32 & 2.3542 & .26690 & & \\
\hline Fluency Sub-dimension & Boy & 28 & 2.0893 & .43148 & -1.903 & .062 \\
& Girl & 32 & 2.2891 & .38158 & & .191 \\
\hline Language Competence- & Boy & 28 & 1.6964 & .33580 & -1.322 & \\
Content Sub-dimension & Girl & 32 & 1.8281 & .42330 & & \\
\hline
\end{tabular}

Based on the result of the $t$ test for the difference of the scores obtained from the Speaking Skills Rating Scale according to gender, the level of expression varies 
significantly according to gender. In the pronunciation sub-dimension, the skill levels of girls $(x=2.35)$ are significantly higher than that of boys $(\bar{x}=2.15)(t=-2.399 ; p<0.05)$.

In the last question of the study, it was aimed to determine whether the speech levels of children differ by age. The result of the $t$ test performed regarding this is given in Table 6.

Table 6. $T$ test result for the difference according to age of the scores obtained from the Speaking Skills Rating Scale

\begin{tabular}{lllllll}
\hline & Age (Month) & $\mathrm{N}$ & Ort. & SS & $\mathrm{t}$ & $\mathrm{p}$ \\
\hline Pronunciation Sub- & $60-66$ months & 39 & 2.2692 & .33028 & .255 & .800 \\
dimension & $67-72$ months & 21 & 2.2460 & .34809 & & .462 \\
\hline Fluency Sub-dimension & $60-66$ months & 39 & 2.1667 & .39874 & -.740 & .44721 \\
& $67-72$ months & 21 & 2.2500 & & .426 \\
\hline Language Competence- & $60-66$ months & 39 & 1.7372 & .38022 & -.801 & .40422 \\
Content Sub-dimension & $67-72$ months & 21 & 1.8214 & & \\
\hline
\end{tabular}

As stated in the results of the $t$ test for the difference of scores obtained from the Speaking Skills Rating Scale according to age, pronunciation $(\mathrm{t}=.255, \mathrm{p}>0.05)$, fluency $(\mathrm{t}$ $=-.740, \mathrm{p}>0.05)$ and language competence and content $(\mathrm{t}=-.801, \mathrm{p}>0.05)$ levels do not differ significantly according to age.

\section{Conclusion and discussion}

Speaking is an extremely important aspect of language acquisition. On the one hand, it reflects the state of the language system acquired through listening, on the other, it reflects the use of cognitive and physical components interactively and in accordance with the context. There are different models showing that individuals carry out many physical and cognitive processes simultaneously during conversation (Bock \& Levelt, 1994; Dell, 1986; Levelt, 1989). Children gain the ability to fulfill this requirement in the process of language acquisition and development. While speaking, they perform many actions such as breathing, pronunciation, sentence and text production at the same time. At this point, the development observed in the preschool period has an important effect. Because it is a rapid process for children to become a natural speaker, but it takes much longer to become a competent speaker (Berman, 2004). The foundations of this development are laid in the preschool period covering the $0-6$ age period.

Findings obtained from the study revealed that 60-72 months old children are not yet competent in terms of speaking skills. For example, it has been found that they are approximately medium in terms of pronunciation, display a rather inadequate appearance in breathing requirements, and are much better at the point of standardization. The result regarding the standardization is thought to be specific to the participating group. Findings related to breathing are consistent with the information in the literature. An important component of the sound system, which is the basis of speech, is the respiratory system (Topbaş, 2010). The correct use of breathing in speaking is a special physical skill. It was found that participants of this study could not perform the correct breathing control during speech; because of that, it was observed that they faced some problems in terms of sound 
production, emphasis and fluency. Considering that the participants are around the age of 5, it can be said that this result is normal. Erdem (2013) states that children can produce sounds that adults make around the age of 6-7. Problems in the nature of articulation disorders, which are also related to breathing in sounds, decrease at the age of 4-5 and disappear over time. (Diken, 2010). While the participants of this research can reproduce many sounds correctly, they only have problems with certain sounds.

The fluency seen in the speeches of the participants is similarly at a medium level. Fluency problems, which appear in the form of word repetitions, extensions or blocks, are problems seen in the natural flow or rhythm of the speech (Kuru, 2013). Considering that the speaking skill consists of comprehensibility, vocabulary, grammar and fluency components (Ertürk, 2006), it is easily understood that the competence of this factor is important for the listener. While the most negative dimension of the fluency levels of the participants is related to naturalness and liveliness, the dimension in which they are at their best is related to pauses. Although there was a lot of pauses in children, it did not affect understanding. On the other hand, the naturalness and liveliness of the speech was found to be significantly inadequate due to the level of fluency. Fluency is defined as the language that a speaker naturally produces and maintains during communication (Richards, 2006). The discontinuity of the language produced affects the fluency. There are also studies showing that fluency problems in children can arise from many different reasons (Guitar, 2013). Some sources underline that fluency problem is an age-related condition and younger ones have more difficulty in achieving fluency (Gordon \& Luper, 1989). It partially explains the fluency problems observed in the age group of participating children in this study. The age group of the participating children in this study partially explains the observed fluency problems Children's problems with fluency may be related to both physical elements such as breathing and cognitive elements such as thought production.

Children showed the least success in terms of language competence and content. Participating children who did not have too many problems with word choice were insufficient in establishing coherence and cohesion relationships. The coherence, which is related to textual qualities, reflects the relationship between sequential phrases and sentences, while the concept of consistency corresponds to semantic-logical relations between larger parts of the text (Keçik \& Uzun-Subaş1, 2003). It is difficult for children to fully establish these relationships around the age of 5 (Özcan, 1993; Van Dam, 2010). However, as the age progresses, children begin to better establish these relationships that form the textual structure (Lee et al., 2013; Saphiro, 1990). Therefore, confronting children with verbal text models that provide these relationships can speed up the process.

Another important finding obtained from the study is that the pronunciation level significantly predicts the level of fluency. Considering the gradual structure of the speech, it is expected that the performance of the pronunciation sufficiently will provide a natural fluency. Because spoken language processing has a hierarchical structure (Davis \& Johnsrude, 2003) and its pronunciation features are one of its lower-level qualities. Therefore, as the pronunciation characteristics of children become more competent, their fluency levels also increase. There are many different variables, including social, linguistic and psychological, that determine fluency (Segalowitz, 2010), however, according to the 
findings, the determinacy level of the pronunciation variable on fluency is quite high for the 5-year-old group (24\%). The reason may be that the pronunciation is of a physical nature and has priority over other variables for children. Children at the age of 5 may not yet be sufficiently aware of the social and psychological dimensions.

The effect of fluency on language competence and content dimension is likewise high. Findings reveal that 5-year-old children who provide fluency in their speech competently can create better structured oral texts. A fluent conversation is an indicator of adequate linguistic processing. For this reason, fluency is defined as the ability to use language quickly and confidently without unnecessary or unnatural pauses in communication that cause some obstacles (Bailey, 2003; Byrne, 1986). Children who have reached this level can establish more competent textual relationships. However, fluency requires using narrative structures that do not have any mistakes that affect the phonetic, syntactic, semantic and discursive features of the language (Byrne, 1986). Therefore, fluency is expected to significantly predict children's language competence.

Considering the speaking skill levels of the children participating in the study, it was found that the girls were better at the pronunciation dimension than the boys, but there was no difference between girls and boys in terms of fluency and language competence. There are many studies showing that girls progress faster than boys in language development (Berk, 1997; Bornstein \& Haynes, 1998; Eriksson et al., 2012; Fenson et al., 1994). The findings obtained from this study coincide with the findings of the mentioned studies. The reason why girls and boys differ in pronunciation dimension, but not to differ in other dimensions may be because pronunciation is acquired earlier than fluency and language competence. The fact that both genders are insufficient especially in terms of language competence suggests that the development at this point has not reached a level that will allow a certain difference to be understood.

Finally, it was determined that the speaking skill levels of the participant children did not differ according to their ages. In this study two groups with a six-month difference between them were formed to examine whether their age had an effect on the speaking skills of the participants. The fact that there is no difference between the 60-72-month-old children in terms of pronunciation, fluency and language competence-content can be attributed to the small difference between the groups. Under normal conditions, the preschool period is considered as a period in which language development progresses rapidly (Hoff, 2009; Kirjavainen et al., 2009). However, it is thought that the age range and certain qualities of the spoken language discussed in this study are not sufficient to see the difference in question.

In summary, according to the results obtained from this study, it can be said that five-year-old children are at a medium level in terms of speaking skills in the process of acquiring Turkish as a mother tongue. While children who are in a better position at the points of pronunciation and fluency still have difficulties in making some sounds, they also face certain problems in terms of fluency. In addition, they have bigger problems in providing language competence and establishing textual relationships. In order to verify and diversify the findings, it is recommended to conduct studies where different data types are used, children with wider age ranges are determined as a sample, and studies using 
measurement tools that take into account other dimensions of speaking skill are recommended.

\section{References}

Alexander, R. (2006). Towards dialogic teaching. Dialogos.

Anlar, B. (1983). Illk altı yaşta dil geliş̧imi, anne baba eğitimi ve cinsiyetin etkisi [Language development in the first six years and the effect of parental education and gender]. Unpublished Specialty Test, Hacettepe University, Ankara.

Bailey, K. M. (2003). Practical English language teaching. McGraw-Hill Contemporary.

Baş, B. (2002). Türkçe Temel Dil Becerilerinin Öğretiminde Atasözlerinin Kullanımı [Use of Proverbs in Teaching Turkish Basic Language Skills]. Pamukkale Üniversitesi Eğitim Fakültesi Dergisi, 12.

Berk, L. E. (1997). Child Development. Allyn and Bacon.

Berman, R. A. (2004). Between emergence and mastery: The long developmental route of language acquisition. In R.A. Berman (Ed.) Language development across childhood and adolescence. John Benjamins.

Biemiller, A. (2006). Vocabulary development and instruction: A prerequisite for school learning. In D. K. Dickinson \& S. B. Neuman (Eds.), Handbook of early literacy research (pp. 4151). Guilford Press.

Biemiller, A. \& Boote, C. (2006). An effective method for building meaning vocabulary in primary grades. Journal of Educational Psychology, 98, 44-62.

Bock, J. K. \& Levelt, W. J. M. (1994). Language production: Grammatical encoding. In M. A. Gernsbacher (Ed.) Handbook of psycholinguistics. Academic Press.

Bornstein, M. H. \& Haynes, O. M. (1998). Vocabulary competence in early childhood: Measurement, latent construct, and predictive validity. Child Development, 69(3), 654671.

Bozkurt, B.Ü. \& Arıca-Akkök, E. (2019). Anadili Türkçe olan konuşucular için konuşma becerisi derecelendirme ölçeğinin geliştirilmesi [Developing a speaking skill rating scale for native Turkish speakers] İlkögretim Online, 18(1), 416-436.

Büyüköztürk, Ş., Çakmak, E. K., Akgün, Ö. E., Karadeniz, Ş. \& Demirel, F. (2008). Bilimsel araştırma yöntemleri [Scientific research methods]. Pegem yayıncılık.

Bradley, L. \& Bryant, P. (1978). Difficulties in auditory organisation as a possible cause of reading backwardness. Nature, 271, 746-747.

Byrne, D. (1986). Teaching oral English. Cambridge University Press.

Coyne, M. D., McCoach, B. \& Kapp, S. (2007). Vocabulary intervention for kindergarten students: Comparing extended instruction to embedded instruction and incidental exposure. Learning Disability Quarterly, 30, 74-88.

Davis, M.H. \& Johnsrude, I. S. (2003). Hierarchical processing in spoken language comprehension, The Journal of Neuroscience, 23(8), 3423-3431.

Dell, G. S. (1986). A spreading-activation theory of retrieval in sentence production. Psychological review, 93(3), 283-321.

Demir, T. (2010). Konuşma eğitiminde benmerkezci konuşmaya yönelik bir deneme [An essay for egocentric speaking in speech education] Kastamonu Ë̆itim Dergisi, 18(2), 415-430. 
Dickinson, D. K., Darrow, C. L. \& Tinubu, T. A. (2008). Patterns of teacher-child conversations in Head Start classrooms: Implications for an empirically grounded approach to professional development. Early Education and Development, 19, 396-429.

Dickinson, D. K. \& Porche, M. V. (2010). Relation between language experiences in preschool classrooms and children's kindergarten and fourth-grade language and reading abilities. Child Development, 82(3), 870-886.

Diken, Ö. (2010). İletişim becerilerinin desteklenmesi [Supporting communication skills] (Editör: İbrahim H. Diken). Illköğretimde kaynaştırma. Pegem Akademi.

Dougherty, C. (2014). Starting off strong: The importance of early learning, American Educator, 18 (2), 14-18.

Erdem, İ. (2013). Konuşma eğitimi esnasında karşılaşılan konuşma bozuklukları ve bunları düzeltme yolları [Speech disorders encountered during speech training and ways to correct them] Adryaman Üniversitesi Sosyal Bilimler Enstitüsü Dergisi (Türkçenin Eğitimi Öğretimi Özel Say1s1), 6(11), 415-452.

Erkan, P. (1990). Sosyo-ekonomik ve eğitim düzeyleri farklı olan ailelerin 48- 60 aylar arasındaki çocuklarının dil yapılarının incelenmesi. [Examination of the language structures of the children between the ages of 48 and 60 months of families with different socio-economic and educational levels] Master Thesis, Hacettepe University, Ankara.

Eriksson, M., Marschik, P. B., Tulviste, T., Almgren, M., Pereira, M. P., Wehberg, S., MarjanovičUmek, L., Gayraud, F., Kovačevič, M. \& Gallego, C. (2012). Differences between girls and boys in emerging language skills: Evidence from 10 language communities. British Journal of Developmental Psychology, 30(2), 326-343.

Ertürk, H. (2006). İngilizce öğretiminde konuşma becerisinin kazandırılmasında yazılı görsel ögretim materyalinin erişime etkisi [The effect of written visual teaching material on access to gaining speaking skills in English language teaching] Unpublished Master Thesis, Hacettepe University, Ankara.

Fenson, L., Dale, P. S., Reznick, J. S., Bates, E., Thal, D. \& Pethick, S. (1994). Variability in early communicative development. Monographs of the Society for Research in Child Development, 59(5), 174-185.

Fromkin, V., Rodman, R. \& Hyams, N. (2011). An introduction to language (9th ed.). Cengage Learning.

Fromkin, V. \& Rodman, R. (1983). An introduction to language (3rd ed.). Holt, Rinehart and Winston.

Gordon, P. A. \& Luper, H. L. (1989). Speech disfluencies in nonstutterers: Syntactic complexity and production task effects. Journal of Fluency Disorders, 14(6), 429-445.

Goswami, U. \& Bryant, P. (1990). Phonological skills and learning to read. Hillsdale: Lawrence Erlbaum.

Guitar, B. (2013). Stuttering: An integrated approach to its nature and treatment (4th Ed.). Lippincott, William \& Wilkins.

Hirsch, E. D. (2006). Building knowledge: The case for bringing content into the language arts block and for knowledge-rich curriculum core for all children. American Educator, 30(1), $8-18$.

Hoff, E. (2009). Language Development (4th ed.). Cengage Learning.

Hoien, T., Lundberg, I., Stanovich, K. \& Bjaalid, I. (1995). Components of phonological awareness. Reading and Writing, 7, 171-188.

İpek, N. (2006). İlköğretim çă̆ı çocuklarında kelime dağarcı̆̆ı gelişimi [Vocabulary development in primary school children] Unpublished Master Thesis, Uludag University, Bursa. 
Karasar, N. (2000). Bilimsel Araştırma Yöntemi [Scientific research method]. (10. Bask1). Nobel Yayın Dağıtım.

Keçik, İ. \& Uzun-Subaş1, L. (2003). Sözlü ve yazılı anlatım üzerine [On verbal and written expression] (Ed. Canan İleri), Türkçe Sözlü ve Yazllı Anlatım içinde, Anadolu Üniversitesi Yayınları.

Kieffer, M. \& Lesaux, N. K. (2012). Knowledge of words, knowledge about words: Dimensions of vocabulary in first and second language learners in sixth grade. Reading and Writing: An Interdisciplinary Journal, 25(2), 347-373.

Kirjavainen, M., Theakston, A., Lieven, E. \& Tomasello, M. (2009). I want hold Postman Pat': an investigation into the acquisition of infinitival marker 'to'. First Language, 29, 313-339.

Koçak, N. \& Dereli, Esra. (2005). Okul öncesi eğitime devam eden 4-6 yaş arasındaki çocukların ifade edici dil düzeylerinin bakım tarzı ve anne- baba eğitim düzeyi açısından incelenmesi [Examining the expressive language levels of children between the ages of 4-6 who attend pre-school education in terms of care style and 128 education level of parents]. Sosyal Bilimler Enstitüsü Dergisi, 14, 245-253.

Kuru, O. (2013). Akıcı konuşma problemi yaşayan ilköğretim 5. sınıf öğrencisinin konuşma becerisini geliştirme [Improving the speaking skills of elementary school 5th grade students who have fluency problems]. Uluslararası Türk Eğitim Bilimleri Dergisi, 1(1), 88-105.

Kurudayığlu, M. (2003). Konuşma eğitimi ve konuşma becerisini geliştirmeye yönelik etkinlikler [Speaking education and activities to improve speaking skills]. Türklük Bilimi Araştırmaları, Türkçenin Öğretimi Özel Sayısı, 13, 267-309.

Lee, Y. J., Lee, G. G. \& Oh, H. N. (2013). An exploratory study on young children's spoken and written narratives of personal experience. Asia-Pacific Journal of Research in Early Childhood Education, 7(2), 47-61.

Levelt, W. J. M. (1989). Speaking: From intention to articulation. M.I.T. Press.

Lundberg, I., Frost, J. \& Peterson, O.-P. (1988). Effects of an extensive program for stimulating phonological awareness in preschool children. Reading Research Quarterly, 33, 263-284.

Lust, B. (2006). Child Language: Acquisition and Growth. Cambridge University Press.

Mercer, N. \& Littleton, N. (2007). Dialogue and the development of children's thinking: A sociocultural approach. Routledge.

O'Grady, W. (2008). How Children Learn Language (5th ed.). Cambridge University Press.

Owens, R. (2012). Language development: An introduction (8th ed.). Pearson.

Özbay, M. (2005). Sesle ilgili kavramlar ve konuşma [Sound concepts and speech]. Milli Eğitim Dergisi, 168, 116-125.

Özcan, F. H. (1993). Coherence in narratives of Turkish-speaking children. (Unpublished doctoral dissertation). University of Reading.

Öztürk, H. (1995). Okulöncesi eğitim kurumlarına giden ve gitmeyen ilkokul birinci sınıf ögrencilerinin alıcı ve ifade edici dil düzeyleri. [Receptive and expressive language levels of primary school first grade students who go to preschool education institutions and who do not] Unpublished Master Thesis, Gazi University, Ankara.

Perfetti, C. (2009). Decoding, vocabulary, and comprehension. In M. McKeown \& L. Kucan (Eds.), Bringing reading research to life (pp. 291-303). Guilford Press.

Resnick, L. B. \& Snow, C. E. (2009). Speaking and listening for preschool through third grade. International Reading Association.

Richards, J. C. (2006). Communicative language teaching today. Cambridge University Press. 
Rowe, M.L., Raudenbush, S.W. \& Goldin-Meadow, S. (2012). The pace of vocabulary growth helps predict later vocabulary skill. Child Development, 83 (2), 508-525.

Scarborough, H. S. (2001). Connecting early language and literacy to later reading (dis)abilities: Evidence, theory, and practice. In S. B. Neuman \& D. K. Dickinson (Eds.), Handbook of early literacy research (pp. 97-110). Guilford Press.

Segalowitz, N. (2010). Cognitive bases of second language fluency. Routledge.

Silverman, R. (2007). A comparison of three methods of vocabulary instruction during read-alouds in kindergarten. Elementary School Journal, 108(2), 97-113.

Stanovich, K. (1992). Speculations on the causes and consequences of the individual differences in early reading acquisition. In P. Gough, L. Ehri and R. Treiman (eds), Reading Acquisition. Hillsdale: Lawrence Erlbaum.

Tabachnick, B. G. \& Fidell, L. S. (2013). Using multivariate statistics (6th ed.), Allyn and Bacon.

Taner, M. (2003). Okul öncesi eğitimi alan ve almayan farkll sosyo-ekonomik düzeylerdeki ilköğretim birinci sınıf ögrencilerinin dil gelişimlerinin karşılaştırılması [Comparison of the language development of primary school first grade students at different socioeconomic levels who received pre-school education and who did not]. Unpublished Master Thesis, Uludag University, Bursa.

Topbaş, S. (2010). Sesbilgisel Gelişim [Phonological Development] (Editör: S. Seyhun Topbaş). Dil ve Kavram Gelişimi. Kök Yayıncılık.

Treiman, R. \& Zukowski, A. (1991). Levels of phonological awareness. In S. Brady and D. Shankweiler (eds), Phonological Processes in Literacy. Hillsdale: Lawrence Erlbaum.

Tural, A. (1977). Ankara'da anaokuluna giden ve gitmeyen 4-6 yaş çocuklarının bildikleri kelime sayısına yaş, cinsiyet, ailenin eğitim düzeyi ve okula devam süresinin etkisi [The effect of age, gender, education level of the family and duration of school attendance on the number of words known by 4-6 year old children who go to kindergarten and not]. Unpublished Master Thesis, Hacettepe University, Ankara.

Van Dam, F. J. (2010). Development of cohesion in normal children's narratives (Research Report). Utrecht: University of Utrecht. http://dspace.library.uu.nl/handle/1874/180044

Van Kleeck, A. (2008). Providing preschool foundations for later reading comprehension: The importance of and ideas for targeting inferencing in storybook-sharing interventions. Psychology in the Schools, 45, 627-643.

Vagh, S.B., Pan, B. A. \& Mancilla-Martinez, J. (2009). Measuring growth in bilingual and monolingual children's English productive vocabulary development: The utility of combining parent and teacher report. Child Development, 80 (5), 1545-1563.

Wells, G. (1999). Dialogic inquiry: Towards a sociocultural practice and theory of education. Cambridge University Press. 


\title{
Dil Eğitimi ve Araştırmaları Dergisi
}

\author{
Araştırma Makalesi
}

\section{0-72 Aylık Çocukların Konuşma Becerilerinin İncelenmesi}

\author{
Begümhan Yüksel*
}

\section{MAKALE BÍLGISİ}

Geliş 18.02.2021

Düzeltme 8.04.2021

Kabul 15.04.2021

Doi:10.31464/jlere. 881497

Anahtar kelimeler:

dil gelişimi

konuşma becerisi

söyleyiş

akıcilık

dil yetkinliği

\section{ÖZET}

$\mathrm{Bu}$ araştırmanın amacı 60-72 ay aralığındaki çocukların konuşma beceri düzeylerini belirlemektir. Araştırmanın çalışma grubunu Antalya il merkezinde 60-72 ay aralığında bulunan 60 çocuk oluşturmaktadır. Veriler "Konuşma Becerisi Değerlendirme Ölçeği” ile toplanmıştır. Bunun için çocuklara kısa bir çizgi film izletilmiş, ardından izlediklerini kendi ifadeleri ile anlatmaları istenmiştir. Araştırmanın verileri bu görüşmelerden elde edilen konuşmaların çözümlenmesi yoluyla elde edilmiştir. Konuşmalar söyleyiş, akıcılık ve dil yetkinliği açısından değerlendirilmiştir. Elde edilen bulgulara göre katılımcı çocukların konuşma becerilerinin söyleyiş ve akıcılık açısından orta düzeyde, dil yetkinliği açısından ortanın altında bir düzeyde olduğu belirlenmiştir. Araştırmadan elde edilen diğer sonuçlara göre söyleyiş beceri düzeyi akıcılığı ve akıcılık düzeyi de dil yetkinliğini yordamaktadır. Söyleyiş özellikleri bakımından kızlar erkeklerden daha başarılıyken akıcılık ve dil yetkinliği açısından aralarında bir fark yoktur. Ayrıca altı aylık yaş farkı söyleyiş, akıcılık ve dil yetkinliği açısından fark yaratan bir değişken değildir. Bu sonuçlara dayanarak diğer yaş gruplarında ve farklı araçlarla çalışmalar yapılması önerilmiştir.

Yayın Etiği Beyanı

$\mathrm{Bu}$ çalışma yayın etik ilkelerine uygun olarak yürütülmüştür. Veriler toplanmadan önce 01.03.2021 tarihinde Sosyal ve Beşeri Bilimler Bilimsel Araştırma ve Yayın Etik Kurulu'ndan 75 numaralı izin alınmıştır.

\footnotetext{
Dr., ORCID ID: https://orcid.org/0000-0002-0869-9157, Akdeniz Üniversitesi, Eğitim Fakültesi, begumhanyuksel@gmail.com
} 


\section{Kuramsal çerçeve}

Çocuklarda gelişim düzeyinin önemli göstergelerinden biri konuşma becerisidir. Sosyal bir çevrede büyüyen çocuk, diğer insanlarla olan etkileşimini konuşma yoluyla gerçekleştirir. Konuşma becerisi çocukların bir yandan sosyal bağlamlara katılımının öncelikli aracıyken diğer yandan bilişsel ve dilsel gelişimle tanımlanan bireysel niteliğini yansıtmasına olanak tanıyan bir beceri türüdür. Çocuklar bu tür deneyimlerini düzenlemek için dili kullanır (Alexander, 2006; Mercer \& Littleton, 2007; Wells, 1999). Dil yoluyla çeşitli bağlamların temel özellikleri anlaşılır ve yine dilin farklı bir beceri boyutu olan konuşmayla bu bağlamlara katılım gösterilir.

Konuşma aynı zamanda okuryazarlığın ve diğer öğrenmelerin de temelini oluşturur. Sessel farkındalık, etkin sözcük dağarcığı, öykü anlatma başarımı gibi noktalar ileride gerçekleşecek okuduğunu anlama ve kod çözme becerisinin önemli işaretleridir (Dickinson \& Porche, 2010; Resnick \& Snow, 2009). Başkalarıyla olan sözel etkileşimlerde çocukların yaptığ 1 sözcük seçimleri, sesletim biçimleri ve bunları gerçekleştirirken oluşturduğu dilsel bağlantılar dil edinim düzeyinin ve sosyal öğrenmelerin önemli işaretlerini içerir. Bu nedenle çocukların gelişim sürecinde belli bir noktadaki konuşma özelliklerinin belirlenmesi birçok öğretim alanının, çalışmanın ve araştırmanın çıkış noktasını oluşturur.

Konuşma dili ileride gerçekleşecek okuma ve yazma öğrenimini de destekler. Okuma ve yazma becerilerinde elde edilecek başarı okulöncesi dönemde öğrenilen konuşma ve dinlemenin uzantısı olarak ortaya çıkar. Dolayısıyla okul öncesi dönemde konuşma becerisi açısından yetersiz olan çocuklar sonraki yıllarda diğer çocuklara ayak uyduramayabilir (Biemiller, 2006; Dougherty, 2014; Scarborough, 2001). Bu durumla karşılaşmamak için çocukların konuşma özelliklerini belirlemek ve kimi eksiklikleri okulöncesi dönemde gidermek gerekir.

Erken çocukluk döneminde konuşma becerisi gelişen çocukların sosyal ilişkileri başlatma ve sürdürme, edindiği yeni bilgileri yorumlama, duygu ve düşüncelerini aktarabilme gibi becerilerde de başarılı oldukları bilinmektedir. Konuşma, sosyalleşmeyi sağlayarak çocukların kendine olan güvenlerini artırmaktadır (Baş, 2002). Başarılı iletişimin anahtarının sesi etkili kullanma ile birlikte güzel ve anlaşılır konuşma olduğu (Kurudayığlu, 2003) düşünüldüğünde konuşmanın çocukların çevresindeki bireylerle anlaşabilmelerinde temel oluşturduğunu söylemek mümkündür. Çocukların konuşma becerileri hem toplum hayatında hem de okul hayatında başarılı olmalarını sağlamaktadır (Demir, 2010). Eğitim kurumlarındaki konuşma derslerinin genel amacının, öğrencilere duygu, düşüncelerini dil kurallarına uygun, doğru ve etkili biçimde anlatma becerisi kazandırmak (Özbay, 2005) olduğu dikkate alındığında erken çocukluk dönemindeki çocukların konuşma becerilerinin de sistemli bir şekilde desteklenmesi gerekmektedir.

Dil birçok bileşenin bir araya gelmesinden oluşan bir dizgedir (Fromkin \& Rodman, 1983). Çok bileşenli bir dizgeyi kullanarak iletişim kurmak ilgili her bileşende belli bir yetkinliğe erişmiş olmayı gerektirir. Dilin öncelikli bileşenleri ses, biçim, sözdizim, anlam ve kullanım noktalarında toplanır. Bu öğelere dilin kullanımını etkileyen dil ötesi bilgiler de eklenebilir. Konuşmayı da içeren dil becerilerinin her kullanımında 
dilin bileşenleri kendi düzlemi içinde işlemeye başlar. Konuşan birey dilin her bir düzleminde belirtilen öğeleri birbiriyle uyumlu biçimde işletir.

Dilsel bilginin önemli bileşenlerinden biri kullanılan seslerin bilgisine sahip olmaktır. Dili kullanan bireyler o dilin seslerini bilmeli ve seslerin birleşme kurallarını konuşma sırasında uygulayabilmelidir. Çocukların konuşma becerisinin ses açıdan değerlendirilmesi sahip olduğu sessel farkındalığa göre yapılabilir. Sessel farkındalık dildeki seslerin nasıl birleştirildiğini ve ne tür bir dağılım gösterdiğini bilmeyi gerektirir. Sessel farkındalık daha sonra edinilecek olan okuma becerisini de önemli ölçüde etkiler (Bradley \& Bryant, 1978; Goswami \& Bryant, 1990; Lundberg vd., 1988). Dil becerilerinin temelini oluşturan seslere yönelik farkındalık heceleri, hecelerin içindeki sesleri ve ses birimsel öğeleri kapsayan üç noktada ele alınır (Treiman \& Zukowski, 1991; Stanovich, 1992; Hoien vd., 1995). Bu noktaların her biri çocukların konuşurken dinleyenin algılayacağı biçimde üretmesi gereken seslere işaret eder.

Dilin sesleri belli anlamların karşılığı olan sözcüklerin ve cümle yapılarının oluşturulması için gerçekleştirilir. Dilsel anlam boyutu konuşma becerisinin bir diğer önemli bileşenidir. Dildeki temel anlamsal birimler sözcüklerdir (Fromkin vd., 2011). Çocukların konuşma becerisini yeterli düzeyde yansıtması dilin belli sözcüklerine sahip olmalarını gerektirir. Hangi sözcüğün hangi anlamla ilişkilendiğini çocuklar yaşadıkları çevreden öğrenir. Öğrenilen sözcükler zihinde sınıflandırılır ve kullanımı sözcük sınıfları üstünden gerçekleşir. Sözgelimi araç sözcügü bir sınıftır ve otomobil, otobüs, tren, vb. alt anlamları içerir (Resnick \& Snow, 2009). Çocuklar bu sözcükleri konuşma sırasında anlamlarına uygun biçimde seçer ve dilbilgisel yapılar içinde kullanır. Çocukların sözcük bilgilerine yönelik yapılan çalışmaların birçoğu daha çok alıcı dille ilgili olarak çeşitli resimleri adlandırmaya dayanan sözcüklere odaklanır (Rowe vd., 2012; Vagh vd., 2009). Perfetti (2009), çocuklardaki sözcük bilgisi farklılı̆̆ına dikkat çeker. Çocuklar okula başladığında sözcük dağarcıklarında hızlı bir gelişim görülür. Sözcük dağarcığı geniş çocukların konuşması daha etkili biçimde gerçekleşir.

Sözcükler dilin biçim birimlerinden biridir. Biçim birimsel boyut sözcükler yanında ekleri de içerir. Sözcüklere ve anlamlarına ilişkin bilgi, onların kullanım sırasındaki çekimlenmiş biçimlerini anlamak ve edinmek için biçim bilimsel bilgiyi de zorunlu kılar. Çoğul, zaman, olumsuzluk, vb. ekler sözcüklerin çocuklara farklı biçimlerde görünmesine neden olur. Dilde anlam ileten en küçük birimleri karşılayan biçimbirimlerin bilgisine sahip çocukların, sözcüklerin kök ve gövdelerine yönelik bilgi yanında eklerin sözcüklere kazandırdığı anlamsal ve işlevsel niteliklerin bilgisine de sahip olduğu düşünülebilir. Dil ediniminin bir boyutu olan konuşma becerisinin gelişimi sözcüklerin farklılaşan biçimlerini kullanabilmeyi gerektirir. Dil kullanıcılarının sözcüklerin sayısı yanında onların derinliğine ilişkin bilgiye sahip olması gerekir (Kieffer \& Lesaux, 2012). Derinlik sözcüklerin değişik biçimlerine yönelik bilginin karşılığıdır.

Çocukların sözcükler açısından gelişiminde onlarla birçok kez karşılaşmış olmaları hem öğrenmeleri hem de belleklerinde tutmaları bakımından son derece önemlidir (Biemiller \& Boote, 2006; Coyne vd., 2007; Silverman, 2007). Sözcüklere ilişkin yeterli gelişim gösteren çocuklar bunları konuşmalarına da yansıtır. Çocukların sözcük dağarcığı okul öncesi dönemden başlayarak önemli farklılıklar gösterir. Okul öncesi dönem 
sözkonusu farklılıkları belirleme açıcından kritik bir öneme sahiptir (Biemiller \& Boote, 2006; Hirsch, 2006). Yapılan çalışmalar okul öncesi öğretmenlerinin çocukların sözcük dağarcığını geliştirmede yeterli stratejileri kullanmadığını ortaya koymuştur (Dickinson vd., 2008; van Kleeck, 2008). Oysa doğru yöntemlerle iyi bir sözcük dağarcığı kazanan çocuklar konuşma becerilerini de geliştirebilir ve sonraki dönemlerde daha başarılı bir öğrenim yaşamı elde edebilir.

Dilin ve konuşmanın zorunlu bir diğer öğesi söz dizimdir. Söz dizimsel bilgi sözcüklerin nasıl birleştirileceğine ilişkin örtük bir bilgi türüdür. Söz dizim yoluyla ayrımsal birimler belli kurallarla birleştirilir (Fromkin vd., 2011). Örtük sözdizimsel kural bilgisi, sözcükleri nasıl birleştirecekleri konusunda bireylere yol gösterir. Başka bir deyişle, bu kurallara göre birleştirilmeyen sözcükler belli bir anlamı karşılayamaz. Dolayısıyla sözdizimsel yapılar sözcükleri birbiriyle ilişkilendirerek kullanmayı gerektirir. $\mathrm{Bu}$ kuralların bilgisine sahip çocuklar iyi yapılanmış tümceler kurabilir. Böylece konuşmaları daha anlaşılır bir duruma gelir.

Dilin kendi iç işleyişini oluşturan bileşenlerin yanında onun kullanım biçimine ilişkin boyutu da sözkonusudur. İlgili bağlamın koşulları temelinde dil her zaman bir amaç için kullanılır. Bireyler dili kullanarak açıklama, bilgi verme, soru sorma, selamlama, vb. amaçları yerine getirir. Dilin değişik bağlamlardaki kullanımına yönelik bilgi onun edimsel boyutuna karşılık gelir. Edim bilim belli sosyal amaçları gerçekleştirmek için dili bir iletişim aracı olarak ele alan disiplinin adıdır (Owens, 2012). Dilin edimsel bilgisine sahip bireyler onu başkalarıyla iletişim sırasında kullandığında ilgili sosyal bağlama dayanarak uygun sözcükleri ve yapıları bulup kullanabilir. Konuşma sırasında dinleyenin tanınıp tanınmamasına, yaşına ya da statüsüne; iletişimin geçtiği bağlamın formal ya da informal olmasına; konuşmacının amacına göre uygun olan yapılar edimsel bilgi yoluyla elde edilir ve kullanılır. Çocukların edimsel bilgisi konuşmalarını doğrudan etkiler.

Alan yazın incelendiğinde okul öncesi dönem çocuklarının konuşma özelliklerini geniş açıdan inceleyen çalışmalara pek rastlanmamıştır. Ancak, çocukların genel dil becerilerini ya da dildeki belli bir noktayı inceleyen kimi çalışmalar bulunmaktadır. Sözgelimi Tural (1977) 4-6 yaş aralığındaki çocukların sözcük dağarcığının çeşitli değişkenlere göre farklılık gösterip göstermediğini inceleyen bir çalışma yapmıştır. Anlar (1983), Denver Gelişimsel Tarama Testini kullanarak 6 yaşına kadar olan çocukların dil gelişimini cinsiyet ve ebeveyn eğitim düzeyi açısından ele alırken Erkan (1990) 4-5 yaş çocuklarının kullandığı dilsel yapıları incelemiş, sözcük sayısı ve türünü odağa alan bir çalışma yapmıştır. Öztürk (1995), Peabody Resim Kelime Testi ve Lügatçe Dil Testini kullanarak çocukların alıcı ve ifade edici dil gelişimlerini incelemiş, Taner (2003) yine Peabody Resim Kelime Testiyle çocukların dil gelişimlerini cinsiyete göre araştırmıştır. Bunun yanında Koçak ve Dereli (2005) 4-6 yaş arasındaki çocukların ifade edici dil düzeylerini araştırmış ve İpek (2006) yine aynı testle çocukların sözcük dağarcığını incelemiştir. Bu çalışmaların birçoğunda sözcügü odağa alan Peabody Resim Kelime Testi kullanıldığı için çalışmaların konuşma becerisi bakımından tek boyutlu olduğu görülmektedir. Türkçede çocukların konuşma becerilerini daha geniş açıdan inceleyen araştırmalara gereksinim olduğu düşünülmektedir. Bu anlayışla bu araştırmada aşağıdaki sorulara yanıt aranmıştır: 
1. Çocukların konuşma becerileri söyleyiş, akıcılık, içerik ve dil kullanımı alt boyutlarında nasıl bir görünüm sergilemektedir?

2. Çocukların konuşma sırasında sergiledikleri söyleyiş becerisi düzeyi akıcılıklarını ne düzeyde yordamaktadır?

3. Çocukların konuşma sırasında sergiledikleri akıcılık düzeyi dil yetkinliği ve içerik boyutunu ne düzeyde yordamaktadır?

4. Çocukların konuşma beceri düzeyi cinsiyete göre farklılaşmakta mıdır?

5. Çocukların konuşma beceri düzeyi yaşa göre farklılaşmakta mıdır?

\section{Yöntem}

Veriler toplanmadan önce 01.03.2021 tarihinde Sosyal ve Beşeri Bilimler Bilimsel Araştırma ve Yayın Etik Kurulu'ndan 75 numaralı izin alınmıştır. Çocukların konuşmalarında görülen özellikleri ana çizgileriyle belirlemeyi amaçlayan bu araştırma ilişkisel tarama modelinde bir çalışmadır. Tarama modelindeki araştırmalarda geçmişte ya da şuan var olan bir durum olduğu biçimiyle betimlenir (Karasar, 2000).

\section{Katılımcilar}

Araştırmanın katılımcılarını Antalya il merkezinde 60-72 ay aralığında toplam 60 okul öncesi çocuğu oluşturmaktadır. Katılımcılar olasılıksız örnekleme türlerinden biri olan uygun örnekleme (convenience sampling) yöntemi kullanılarak oluşturulmuştur. Uygun örnekleme yönteminde ihtiyaç duyulan büyüklükteki bir gruba ulaşılana kadar en ulaşılabilir olan yanıtlayıcılardan başlamak üzere örneklem oluşturulur ya da en ulaşılabilir ve maksimum tasarruf sağlayacak bir durum, örnek üzerinde çalışılır (Büyüköztürk vd. 2008).

\%46.7'si (n=28) erkek, \%53.3'si (n=32) kız çocuktan oluşan katılımcıların \%65.0'i $(n=39)$ 60-66 aylık iken \%35.0’i $(n=21)$ 67-72 aylık arasındadır. Katılımcıların yaş olarak 60-72 ay (5 yaş) aralığından seçilmesinin nedeni konuşma becerilerine yönelik belli bir düzeye erişmiş olduklarının düşünülmesidir. Alanyazında çocukların üç yaş dolaylarında dil dizgesini öğrendikleri belirtilir (Lust, 2006; O‘Grady, 2008). 4-5 yaşa ulaşan çocuk edindiği dil dizgesiyle belli bağlamlarda iletişim kurmaya başlar. Sözcük dağarcıkları gelişir ve daha karmaşık nitelikli sözdizimsel yapıları kullanmaya çalışırlar. 60-72 ay aralığındaki katılımcıların 60-66 ve 67-72 olarak iki ayrı grupta ele alınmasının nedeni ise okul öncesi dönemde çocukların dil gelişiminin insan yaşamında hiç olmadığ kadar hızlı olmasıdır (Hoff, 2009; Kirjavainen vd., 2009).

Katılımcıların demografik özelliklerine yönelik bilgiler aşağıda Tablo 1'de sunulmuştur.

Tablo 1. Katılımcılara İlişkin Demografik Bilgiler

\begin{tabular}{llcc}
\hline & & Kişi sayısı & $\%$ \\
\hline Cinsiyet & Erkek & 28 & 46.7 \\
& Kız & 32 & 53.3 \\
& Toplam & 60 & 100.0 \\
\hline Yaş (ay) & $60-66$ & 39 & 65.0
\end{tabular}




\begin{tabular}{lcc}
\hline $67-72$ & 21 & 35.0 \\
Toplam & 60 & 100.0 \\
\hline
\end{tabular}

\section{Veri toplama aracı}

Araştırmanın verilerinin toplanmasında katılımcı çocukların demografik bilgilerini edinmek üzere araştırmacı tarafından oluşturulan Kişisel Bilgi Formu kullanılmıştır. Araştırmada kullanılan ikinci araç Bozkurt ve Arıca-Akkök (2019) tarafından geliştirilen Konuşma Becerisi Değerlendirme Ölçeği (KBDÖ)'dir. Bu ölçek belli bir konuşucunun zayıf ve güçlü olduğu alanların belirlenmesine olanak sağlayacak biçimde tasarlanmıştır. Söyleyiş, akıcılık, dil yetkinliği ve etkileşim/sunum boyutlarından oluşan ölçekte her bir boyut ayrı ayrı kullanılabilecek niteliktedir. Ölçekte yer alan boyutların ilk üçü dereceli puanlama anahtarı yapısında tasarlanmışken etkileşim/sunum boyutu istatistiksel süreçler nedeniyle dereceli gözlem formu olarak oluşturulmuştur. Ölçekteki maddeler zaylf, gelişstirilebilir, yeterli ve yetkin terimleriyle derecelendirilmiştir. Maddelerin KGİ hesaplaması uzman görüşlerine başvurularak yapılmış; söyleyiş, akıcılık ve dil yetkinliği boyutunda yer alan maddelerin tümünün KGI hesaplaması 1.0 olarak belirlenmiştir. Etkileşim/sunum boyutundaki maddelere bakıldığında ise yalnızca iki maddenin KGİ hesaplamasının 0.8 değerinde, diğer maddelerin ise 1.0 değerinde olduğu görülmektedir. Dolayısıyla bu ölçek konuşma becerisini değerlendirmede güvenilirliği yüksek bir ölçektir. $\mathrm{Bu}$ araştırmada ölçeğin yalnızca söyleyiş, akıcılık ve dil yetkinliği-içerik boyutları kullanılmıştır.

\section{Verilerin toplanması ve çözümlenmesi}

Veriler toplanmadan önce 01.03.2021 tarihinde Sosyal ve Beşerî Bilimler Bilimsel Araştırma ve Yayın Etiği Kurulu tarafından 75 sayılı Etik Kurul izni alınmıştır. Araştırmaya katılan çocuk katılımcılarının konuşma becerisini değerlendirmek için onlara kısa bir çizgi film izletilmiş ve bu filmde gördüklerini anlatmaları istenmiştir. Alınan izinlere dayanarak çocukların anlatımlarının ses ve görüntü kaydı alınmıştır. Kayıtlar iki uzman tarafından Konuşma Becerisi Değerlendirme Ölçeği kullanılarak değerlendirilmiştir. Değerlendirmeler sonucunda uzmanlar arasındaki uyuşum yüzdesine bakılmış ve yapılan hesaplama sonucunda uyuşumun .91 değerinde olduğu belirlenmiştir.

Katılımcılarından toplanan veriler tek oturumda elde edilmiştir. Konuşmalar ölçekteki maddeler açısından değerlendirilerek puanlanmış ve puanlar istatistik programına aktarılmıştır. İstatistik programında kullanılacak teknikler araştırma sorularının niteliğine göre belirlenmiştir. Analizler yapılmadan önce verilerin dağılımına bakılmıştır. Bunun için katılımcıların ölçeğin alt boyutlarından aldıkları toplam puan hesaplanmış, daha sonra bu puanların dağılımına ilişkin Skewness ve Kurtosis değerleri ile merkezi eğilim ölçülerine ve Shapiro Wilk testinin sonucuna bakılmıştır. Skewness ve Kurtosis değerlerinin +1.5 ile -1.5 arasında olduğu görülmüş ve dağılım normal kabul edilmiş̧ir (Tabachnick \& Fidell, 2013). Shapiro Wilk testinde ise p>.05 eşitsizliği sağlanmıştır. $\mathrm{Bu}$ sonuç da dağılımın normal olduğunu göstermiştir. Sonuç olarak KBDÖ'den elde edilen puanların normal bir dağılıma sahip olduğu tespit edilmiştir. Bu sebeple KBDÖ'den alınan puanların cinsiyete ve yaşa göre farklılığına yönelik analizlerde 
Bağımsız Gruplar İçin T Testi uygulanmıştır. KBDÖ Söyleyiş alt boyutunun Akıcılık alt boyutunu yordama düzeyi ile KBDÖ Akıcılık alt boyutunun dil yetkinliği ve içerik alt boyutunu yordama düzeyinin belirlenmesinde ise basit doğrusal regresyon analizinden faydalanılmıştır.

\section{Bulgular}

Araştırmanın ilk sorusunda çocukların konuşma beceri düzeylerinin söyleyiş, akıcılık, dil yetkinliği ve içerik alt boyutlarında ne düzeyde olduğunu belirlemek amaçlanmıştır. Bunun için yapılan analizin sonuçları Tablo 2'de gösterilmiştir.

Tablo 2. Konuşma Becerisi Derecelendirme Ölçeği Söyleyiş, Akıcılık ve Dil Yetkinliği-İçerik Alt Boyutlarından Alınan Puanların Ortalamaları

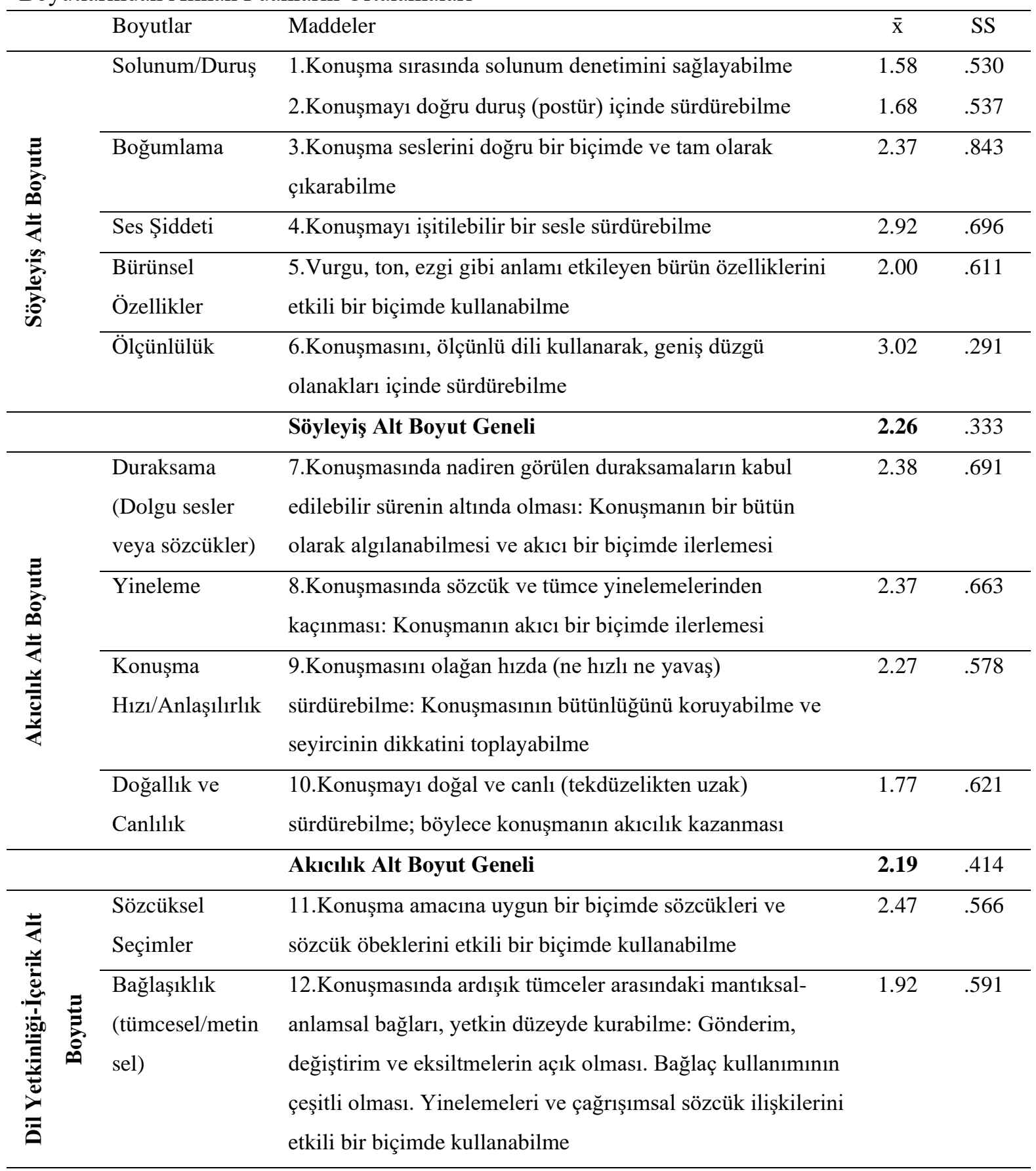




\begin{tabular}{llcc} 
Tutarlılık & 13.Konuşmasının büyük anlamsal birimleri arasındaki & 1.43 & .533 \\
(metinsel) & mantıksal-anlamsal tutarlılığın yetkin düzeyde olması: & & \\
& Konuşmayı, sapmalardan kaçınarak, amaca uygun bir & & \\
& biçimde sürdürebilme & & \\
\hline Üst metinsel ve & 14.Konuşmasının konuşma amacının gerektirdiği üst & 1.25 & .437 \\
söylemsel & metinsel ve söylemsel yapıya sahip olması: Beklenen söylem & & \\
düzenleme & kalıplarını ve üst metinsel yönlendiricileri etkili bir biçimde & & \\
& kullanabilme & & \\
& Dil Yetkinliği-İçerik Alt Boyut Geneli & $\mathbf{1 . 7 6}$ & .387 \\
\hline
\end{tabular}

Tablo 2'de görüldüğü gibi katılımcı çocuklar söyleyiş alt boyutunda 2.26 ortalamaya, akıcılık alt boyutunda 2.19 ortalamaya ve dil yetkinliği-içerik alt boyutunda 1.76 ortalamaya erişmişlerdir. Konuşma Becerisi Değerlendirme Ölçeği’nde yer alan maddelerden en az 1 ve en fazla 4 puan alındığı düşünüldüğünde söyleyiş ve akıcılık boyutlarında çocukların ortanın çok az üstünde, ancak dil yetkinliği-içerik boyutunda ortanın biraz altında bir düzeyde oldukları söylenebilir. Bunun yanında madde bazında çocukların düzeyleri yukarıdaki tabloya yansıtılmıştır.

Araştırmanın ikinci sorusunda çocukların söyleyiş becerisi düzeylerinin akıcılıklarını ne oranda yordadığını belirlemek amaçlanmıştır. $\mathrm{Bu}$ noktaya yönelik uygulanan regresyon analizinin sonuçları Tablo 3 'te gösterilmiştir.

Tablo 3. Konuşma Becerisi Derecelendirme Ölçeği Söyleyiş Alt Boyutunun Akıcılık Alt Boyutunu Yordama Düzeyine İlişkin Basit Doğrusal Regresyon Analizi Sonucu

\begin{tabular}{llllll}
\hline Akıcılık & $\mathrm{B}$ & $\mathrm{Sh}$ & $\beta$ & $\mathrm{t}$ & $\mathrm{p}$ \\
\hline Sabit & .815 & .324 & & 2.513 & .015 \\
Söyleyiş & .611 & .142 & .492 & 4.302 & .000
\end{tabular}

$\mathrm{n}=60, \mathrm{R}=.49, \mathrm{R}^{2}=.24, \mathrm{~F}=18.50, \mathrm{p}<0.01$

Yapılan basit doğrusal regresyon analizinin sonucuna göre konuşma becerisi derecelendirme ölçeğinin alt boyutlarından söyleyiş alt boyutuna ilişkin beceri düzeyinin akıcılık alt boyutuna ilişkin beceri düzeyini anlamlı ve pozitif biçimde yordadı̆̆ görülmüştür $\left(\mathrm{R}=.49, \mathrm{R}^{2}=.24, \mathrm{~F}=18.50, \mathrm{p}<0.01\right)$. Tabloya göre söyleyiş alt boyutuna ilişkin beceri düzeyi akıcılık alt boyutuna ilişkin beceri düzeyindeki toplam varyansın \%24'ünü açıklamaktadır.

Araştırmanın üçüncü sorusunda çocukların akıcılık düzeylerinin dil yetkinliği ve içerik düzeylerini ne oranda yordadığını belirlemek amaçlanmıştır. Bunun için uygulanan regresyon analizinin sonuçları Tablo 4'te sunulmuştur.

Tablo 4. Konuşma Becerisi Derecelendirme Ölçeği Akıcılık Alt Boyutunun Dil Yetkinliği ve İçerik Alt Boyutunu Yordama Düzeyine İlişsin Basit Doğrusal Regresyon Analizi Sonucu

\begin{tabular}{llllll}
\hline Dil Yetkinliği ve İçerik & $\mathrm{B}$ & $\mathrm{Sh}$ & $\beta$ & $\mathrm{t}$ & $\mathrm{p}$ \\
\hline Sabit & .631 & .228 & & 2.763 & .008 \\
Akıcılık & .517 & .102 & .553 & 5.057 & .000 \\
\hline $\mathrm{n}=60, \mathrm{R}=.55, \mathrm{R}^{2}=.30, \mathrm{~F}=25.57, \mathrm{p}<0.01$ & & & &
\end{tabular}


Yapılan basit doğrusal regresyon analizinin sonucuna göre konuşma becerisi derecelendirme ölçeğinin alt boyutlarından akıcılık alt boyutuna ilişkin beceri düzeyinin dil yetkinliği ve içerik alt boyutuna ilişkin beceri düzeyini anlamlı ve pozitif biçimde yordadığı görülmüştür $\left(\mathrm{R}=.55, \mathrm{R}^{2}=.30, \mathrm{~F}=25.57, \mathrm{p}<0.01\right)$. Tabloya göre akıc1lık alt boyutuna ilişkin beceri düzeyi dil yetkinliği ve içerik alt boyutuna ilişkin beceri düzeyindeki toplam varyansın \%30’unu açıklamaktadır.

Araştırmanın dördüncü sorusunda çocukların konuşma düzeylerinin cinsiyete göre farklılaşıp farklılaşmadığını belirlemek amaçlanmıştır. Bu noktaya yönelik uygulanan $t$ testi sonucu Tablo 5'te verilmiştir.

Tablo 5. Konuşma Becerisi Derecelendirme Ölçeği'nden Alınan Puanların Cinsiyete Göre Farklılı̆̆ına Yönelik T Testi Sonucu

\begin{tabular}{lllllll}
\hline & Cinsiyet & $\mathrm{N}$ & Ort. & $\mathrm{SS}$ & $\mathrm{t}$ & $\mathrm{p}$ \\
\hline Söyleyiş Alt Boyutu & Erkek & 28 & 2.1548 & .37386 & -2.399 & .020 \\
& $\mathrm{~K} 1 \mathrm{z}$ & 32 & 2.3542 & .26690 & & \\
\hline Akıcılık Alt Boyutu & Erkek & 28 & 2.0893 & .43148 & -1.903 & .062 \\
& $\mathrm{~K} 1 \mathrm{z}$ & 32 & 2.2891 & .38158 & & \\
\hline Dil Yetkinliği ve İçerik & Erkek & 28 & 1.6964 & .33580 & -1.322 & .191 \\
Alt Boyutu & Kiz & 32 & 1.8281 & .42330 & & \\
\hline
\end{tabular}

Konuşma Becerisi Derecelendirme Ölçeği'nden alınan puanların cinsiyete göre farklılığına yönelik yapılan $t$ testinin sonucuna göre söyleyiş düzeyleri cinsiyete göre anlamlı bir farklılık göstermektedir. Söyleyiş alt boyutunda kız çocukların beceri düzeyleri $(\overline{\mathrm{x}}=2.35)$ erkek çocukların beceri düzeylerinden $(\overline{\mathrm{x}}=2.15)$ anlamlı biçimde yüksektir $(\mathrm{t}=-$ 2.399; $\mathrm{p}<0.05)$.

Araştırmanın son sorusunda çocukların konuşma düzeylerinin yaşa göre farklılaşıp farklılaşmadığını saptamak amaçlanmıştır. Bununla ilgili gerçekleştirilen t testi sonucu Tablo 6'da verilmiştir.

Tablo 6. Konuşma Becerisi Derecelendirme Ölçeği Alt Boyutlarından Alınan Puanların Yaşa Göre Farklılığına Yönelik T Testi Sonucu

\begin{tabular}{lllllll}
\hline & Yaş (Ay) & N & Ort. & SS & t & $\mathrm{p}$ \\
\hline Söyleyiş Alt Boyutu & 60-66 aylık & 39 & 2.2692 & .33028 & .255 & .800 \\
& 67-72 aylık & 21 & 2.2460 & .34809 & & \\
\hline Akıcılık Alt Boyutu & 60-66 aylık & 39 & 2.1667 & .39874 & -.740 & .462 \\
& 67-72 aylık & 21 & 2.2500 & .44721 & & .426 \\
\hline Dil Yetkinliği ve İçerik Alt & $60-66$ aylık & 39 & 1.7372 & .38022 & -.801 & .40422 \\
Boyutu & $67-72$ aylık & 21 & 1.8214 & & \\
\hline
\end{tabular}

Konuşma Becerisi Derecelendirme Ölçeği'nden alınan puanların yaşa göre farklılığına yönelik yapılan $\mathrm{t}$ testinin sonucuna göre söyleyiş $(\mathrm{t}=.255, \mathrm{p}>0.05)$, akıcılık ( $\mathrm{t}=-$ $.740, \mathrm{p}>0.05)$ ve dil yetkinliği ve içerik $(\mathrm{t}=-.801, \mathrm{p}>0.05)$ düzeyleri yaşa göre anlamlı bir farkl111k göstermemektedir. 


\section{Sonuç ve Tartışma}

Konuşma, dil ediniminin son derece önemli bir boyutudur. Bir yandan dinleme yoluyla edinilen dil dizgesinin durumunu yansıtırken diğer yanıyla bilişsel ve fiziksel bileşenlerin etkileşimsel olarak ve bağlamla uyumlu biçimde kullanımını yansıtır. Konuşma sırasında bireylerin birçok fiziksel ve bilişsel işlemi aynı anda yürüttüğünü gösteren değişik modeller vardır (Bock \& Levelt, 1994; Dell, 1986; Levelt, 1989). Çocuklar dil edinimi ve gelişimi sürecinde bu gerekliliği yerine getirme becerisini kazanır. Konuşurken solunum, sesletim, tümce ve metin üretimi gibi birçok edimi aynı anda gerçekleştirirler. Bu noktada okulöncesi dönemde gözlenen gelişimin önemli bir etkisi vardır. Çünkü çocukların doğal bir konuşucu durumuna gelmesi hızlı gerçekleşen bir süreçtir, ancak yetkin bir konuşucu olması çok daha uzun zaman alır (Berman, 2004). Bu gelişimin temelleri 0-6 yaş dönemini kapsayan okul öncesi dönemde atılır.

Araştırmadan elde edilen bulgular, 60-72 aylık çocukların konuşma becerisi bakımından henüz yetkin bir durumda olmadığını ortaya koymuştur. Örneğin söyleyiş özellikleri bakımından yaklaşık orta düzeyde oldukları, solunumla ilgili gerekliliklerde oldukça yetersiz bir görünüm sergiledikleri ve ölçünlülük noktasında ise çok daha iyi durumda oldukları bulgulanmıştır. Ölçünlülükle ilgili sonucun katılımcı gruba özgü olduğu düşünülmektedir. Solunuma ilişkin bulgular ise alanyazında yer alan bilgilerle tutarlılık göstermektedir. Konuşmanın dayanağı olan ses sisteminin önemli bir bileşeni solunum aygitıdır (Topbaş, 2010). Konuşmada solunumu doğru kullanabilmek fiziksel nitelikli özel bir beceridir. $\mathrm{Bu}$ araştırmanın katılımcıları konuşma sırasında doğru solunum denetimi yapamadığı; bu nedenle de ses üretimi, vurgu ve akıcılık açısından birtakım sorunlarla karşılaştıkları görülmüştür. Katılımcıların 5 yaş dolaylarında olduğu düşünülürse bu sonucun normal olduğu söylenebilir. Erdem (2013) yetişkinlerin çıkardığ 1 sesleri çocukların 6-7 yaş dolaylarında çıkarabildiğini belirtir. Seslerde görülen solunumla da ilişkili olan artikülasyon bozuklukları niteliğindeki sorunlar 4-5 yaşlarında azalır ve zamanla kaybolur (Diken, 2010). Bu araştırmanın katılımcıları da birçok sesi doğru biçimde üretebilirken yalnızca belli seslerde sorun yaşamaktadır.

Katılımcıların konuşmalarında görülen akıcılık da benzer biçimde orta düzeydedir. Sözcük yinelemeleri, uzatmalar ya da engellemeler biçiminde beliren akıcılık sorunları konuşmanın doğal akışı ya da ritminde görülen sorunlardır (Kuru, 2013). Konuşma becerisinin anlaşılabilirlik, sözcük bilgisi, dilbilgisi ve akıcılık bileşenlerinden oluştuğu dikkate alındığında (Ertürk, 2006) bu etmenin yeterliliğinin dinleyen açısından önemli olduğu kolayca anlaş1lır. Katılımcıların akıcılık düzeylerinin en olumsuz olduğu boyut doğallık ve canlılıkla ilişkiliyken en iyi durumda olduğu boyut duraksamalarla ilgilidir. Çocuklarda duraksama fazlaca olsa da anlamayı etkilememiştir. Buna karşın konuşmanın doğallığı ve canlılığ1 akıcılık düzeyinden dolayı önemli ölçüde yetersiz bulunmuştur. Akıcılık, bir konuşmacının iletişim sırasında doğal biçimde ürettiği ve sürdürdüğü dil olarak tanımlanır (Richards, 2006). Üretilen dilin sürekliliğinin bozulması akıcılığı etkiler. Çocuklardaki akıcılık sorunlarının birçok farklı nedenden kaynaklanabileceğini gösteren çalışmalar da vardır (Guitar, 2013). Ayrıca kimi kaynaklarda akıcılık sorununun yaşa bağlı bir durum olduğu, yaşı küçük olanların akıcılığı sağlamada daha fazla güçlük yaşadığını da belirtir (Gordon \& Luper, 1989). Bu araştırmadaki katılımcı çocukların da yaş grubu 
görülen akıcılık sorunlarını kısmen açıklamaktadır. Çocukların akıcılıkta sorun yaşaması hem solunum gibi fiziksel öğelerle hem de düşünce üretimi gibi bilişsel öğelerle ilişkili olabilir.

Çocuklar dil yetkinliği ve içerik boyutunda en düşük başarıyı göstermiştir. Sözcük seçimi konusunda çok fazla sorun yaşamayan katılımcı çocuklar tutarlılık ve bağlaşıklık ilişkilerini kurmada yetersiz kalmışlardır. Metinsel niteliklerle ilgili olan bağlaşıklık art arda sıralanan sözcük öbekleri ve tümceler arasındaki ilişkiyi yansıtırken tutarlılık kavramı metnin daha büyük bölümleri arasındaki anlamsal-mantıksal bağıntılara karşılık gelir (Keçik \& Uzun-Subaşı, 2003). Çocukların bu ilişkileri 5 yaş civarında tam olarak kurabilmesi güçtür (Özcan, 1993; Van Dam, 2010). Ancak yaş ilerledikçe metinsel yapıyı oluşturan bu ilişkileri çocuklar daha iyi kurmaya başlar (Lee vd., 2013; Saphiro, 1990). Dolayısıyla çocukları bu ilişkilerin sağlandığı doğru sözlü metin modelleriyle karşılaştırmak bu süreci hızlandırabilir.

Çalışmadan elde edilen bir diğer önemli bulgu söyleyiş düzeyinin akıcılık düzeyini anlamlı ölçüde yordadığına yönelik bulgudur. Konuşmanın aşamalı yapısı düşünüldüğünde söyleyiş edimlerinin yeterli ölçüde gerçekleştirilmesinin doğal bir akıcılığı sağlaması beklenir. Çünkü konuşma dilindeki işlemleme hiyerarşik bir yapıya sahiptir (Davis \& Johnsrude, 2003) ve söyleyiş özellikleri onun alt düzeyde bulunan niteliklerinden biridir. Dolayısıyla çocukların söyleyiş özellikleri yetkinleştikçe akıcılık düzeyleri de artmaktadır. Akıcılığı belirleyen sosyal, dilbilimsel ve psikolojik olmak üzere birçok farklı değişken vardır (Segalowitz, 2010), ancak elde edilen bulgulara göre 5 yaş grubu için söyleyiş değişkeninin akıcılık üstündeki belirleyicilik düzeyi oldukça yüksektir (\%24). Bunun nedeninin söyleyişin fiziksel nitelikli olması ve çocuklar açısından diğer değişkenlere göre daha öncelikli olması olabilir. 5 yaş düzeyindeki çocuklar sosyal ve psikolojik boyutların henüz yeterince farkında olmayabilir.

Akıcılığın dil yetkinliği ve içerik boyutu üstündeki etkisi de aynı biçimde yüksektir. Elde edilen bulgulara göre konuşmasında akıcılığ 1 yetkin biçimde sağlayan 5 yaşındaki çocuklar daha iyi yapılanmış sözlü metinler kurabilmektedir. Akıcı bir konuşma, dilsel işlemlemenin yeterli biçimde yapıldığının göstergesidir. $\mathrm{Bu}$ nedenle akıcılık, iletişimde bazı engellerin oluşmasına neden olan gereksiz ya da doğal olmayan duraklamalar olmadan hızlı ve emin olarak dilin kulanım becerisi olarak tanımlanır (Bailey, 2003; Byrne, 1986). Bu düzeye gelmiş çocuklar daha yetkin metinsel ilişkiler kurabilir. Bununla birlikte akıcılık dilin sessel, sözdizimsel, anlamsal ve söylemsel özelliklerini etkileyen yanlışların olmadığı anlatım yapılarını kullanmayı gerektirir (Byrne, 1986). Dolayısıyla akıcılığın çocukların dil yetkinliğini önemli oranda yordaması beklenen bir durumdur.

Araştırmaya katılan çocukların konuşma becerisi düzeylerine bakıldığında kızların erkeklerden söyleyiş boyutunda daha iyi durumda oldukları, ancak akıcılık ve dil yetkinliği boyutlarında kızlarla erkekler arasında bir fark olmadığı bulgulanmıştır. Dil gelişiminde kızların erkeklerden daha hızlı yol aldığını gösteren birçok araştırma vardır (Berk, 1997; Bornstein \& Haynes, 1998; Eriksson vd., 2012; Fenson vd., 1994). Bu çalışmadan elde edilen bulgu sözü edilen araştırmaların bulgularıyla örtüşmektedir. Kızlarla erkeklerin söyleyiş boyutunda farklı olmaları, ancak diğer boyutlarda aralarında fark olmamasının 
nedeni söyleyişin akıcılık ve dil yetkinliğine oranla daha erken kazanılması olabilir. Özellikle dil yetkinliği konusunda her iki cinsiyetin de yetersiz olması bu noktadaki gelişimin belli bir farkın anlaşılmasına sağlayacak düzeye gelmemiş olduğunu düşündürmektedir.

Son olarak katılımcı çocukların konuşma beceri düzeylerinin yaşlarına göre belli bir farklılık göstermediği belirlenmiştir. $\mathrm{Bu}$ çalışmadaki katılımcıların konuşma becerisinde yaşlarının bir etkisi olup olmadığına bakmak için aralarında altı aylık fark olan iki grup oluşturulmuştur. Tamamı 60-72 aylık çocukların söyleyiş, akıcılık ve dil yetkinliği-içerik bakımından aralarında bir fark olmaması gruplar arasındaki farkın az olmasına bağlanabilir. Normal şartlarda okul öncesi dönem dil gelişiminin hızlı biçimde yol aldığı bir dönem olarak kabul edilir (Hoff, 2009; Kirjavainen vd,. 2009). Ancak bu çalışmada ele alınan yaş aralığının ve konuşma dilinin belli niteliklerinin sözkonusu farkı görmede yeterli olmadığı düşünülmektedir.

Özetle bu çalışmadan elde edilen sonuçlara göre beş yaşındaki çocukların Türkçeyi anadili olarak edinme sürecinde konuşma becerisi açısından orta düzeyde oldukları söylenebilir. Söyleyiş ve akıcılık noktalarında daha iyi bir durumda olan çocuklar bazı sesleri çıkarmakta yine de güçlük yaşarken akıcılık noktasında da belli sorunlarla karşılaşmaktadırlar. Bunun yanında dil yetkinliğini sağlama ve metinsel ilişkileri kurma noktasında daha büyük sorunlara sahiptirler. Elde edilen bulguları doğrulamak ve çeşitlendirmek amacıyla farklı veri türlerinin kullanıldığg, daha geniş yaş aralıklarına sahip çocukların örneklem olarak belirlendiği ve konuşma becerisinin diğer boyutlarını dikkate alan ölçme araçlarının kullanıldığı çalışmalar yapılması önerilmektedir.

\section{Kaynakça}

Alexander, R. (2006). Towards dialogic teaching. Dialogos.

Anlar, B. (1983). Illk altı yaşta dil gelişimi, anne baba eğitimi ve cinsiyetin etkisi [Language development in the first six years and the effect of parental education and gender]. Unpublished Specialty Test, Hacettepe University, Ankara.

Bailey, K. M. (2003). Practical English language teaching. McGraw-Hill Contemporary.

Baş, B. (2002). Türkçe Temel Dil Becerilerinin Öğretiminde Atasözlerinin Kullanımı [Use of Proverbs in Teaching Turkish Basic Language Skills]. Pamukkale Üniversitesi Eğitim Fakültesi Dergisi, 12.

Berk, L. E. (1997). Child Development. Allyn and Bacon.

Berman, R. A. (2004). Between emergence and mastery: The long developmental route of language acquisition. In R.A. Berman (Ed.) Language development across childhood and adolescence. John Benjamins.

Biemiller, A. (2006). Vocabulary development and instruction: A prerequisite for school learning. In D. K. Dickinson \& S. B. Neuman (Eds.), Handbook of early literacy research (pp. 4151). Guilford Press.

Biemiller, A. \& Boote, C. (2006). An effective method for building meaning vocabulary in primary grades. Journal of Educational Psychology, 98, 44-62.

Bock, J. K. \& Levelt, W. J. M. (1994). Language production: Grammatical encoding. In M. A. Gernsbacher (Ed.) Handbook of psycholinguistics. Academic Press. 
Bornstein, M. H. \& Haynes, O. M. (1998). Vocabulary competence in early childhood: Measurement, latent construct, and predictive validity. Child Development, 69(3), 654671.

Bozkurt, B.Ü. \& Arıca-Akkök, E. (2019). Anadili Türkçe olan konuşucular için konuşma becerisi derecelendirme ölçeğinin geliştirilmesi [Developing a speaking skill rating scale for native Turkish speakers] Illkögretim Online, 18(1), 416-436.

Büyüköztürk, Ş., Çakmak, E. K., Akgün, Ö. E., Karadeniz, Ş. \& Demirel, F. (2008). Bilimsel araştırma yöntemleri [Scientific research methods]. Pegem yayıncılık.

Bradley, L. \& Bryant, P. (1978). Difficulties in auditory organisation as a possible cause of reading backwardness. Nature, 271, 746-747.

Byrne, D. (1986). Teaching oral English. Cambridge University Press.

Coyne, M. D., McCoach, B. \& Kapp, S. (2007). Vocabulary intervention for kindergarten students: Comparing extended instruction to embedded instruction and incidental exposure. Learning Disability Quarterly, 30, 74-88.

Davis, M.H. \& Johnsrude, I. S. (2003). Hierarchical processing in spoken language comprehension, The Journal of Neuroscience, 23(8), 3423-3431.

Dell, G. S. (1986). A spreading-activation theory of retrieval in sentence production. Psychological review, 93(3), 283-321.

Demir, T. (2010). Konuşma eğitiminde benmerkezci konuşmaya yönelik bir deneme [An essay for egocentric speaking in speech education] Kastamonu Eğitim Dergisi, 18(2), 415-430.

Dickinson, D. K., Darrow, C. L. \& Tinubu, T. A. (2008). Patterns of teacher-child conversations in Head Start classrooms: Implications for an empirically grounded approach to professional development. Early Education and Development, 19, 396-429.

Dickinson, D. K. \& Porche, M. V. (2010). Relation between language experiences in preschool classrooms and children's kindergarten and fourth-grade language and reading abilities. Child Development, 82(3), 870-886.

Diken, Ö. (2010). İletişim becerilerinin desteklenmesi [Supporting communication skills] (Editör: İbrahim H. Diken). Illköğretimde kaynaştırma. Pegem Akademi.

Dougherty, C. (2014). Starting off strong: The importance of early learning, American Educator, 18 (2), 14-18.

Erdem, İ. (2013). Konuşma eğitimi esnasında karşılaşılan konuşma bozuklukları ve bunları düzeltme yollar1 [Speech disorders encountered during speech training and ways to correct them] Adıyaman Üniversitesi Sosyal Bilimler Enstitüsü Dergisi (Türkçenin Eğitimi Öğretimi Özel Sayıs1), 6(11), 415-452.

Erkan, P. (1990). Sosyo-ekonomik ve eğitim düzeyleri farklı olan ailelerin 48- 60 aylar arasındaki çocuklarının dil yapılarının incelenmesi. [Examination of the language structures of the children between the ages of 48 and 60 months of families with different socio-economic and educational levels] Master Thesis, Hacettepe University, Ankara.

Eriksson, M., Marschik, P. B., Tulviste, T., Almgren, M., Pereira, M. P., Wehberg, S., MarjanovičUmek, L., Gayraud, F., Kovačevič, M. \& Gallego, C. (2012). Differences between girls and boys in emerging language skills: Evidence from 10 language communities. British Journal of Developmental Psychology, 30(2), 326-343.

Ertürk, H. (2006). Ingilizce öğretiminde konuşma becerisinin kazandırılmasında yazılı görsel ögretim materyalinin erişime etkisi [The effect of written visual teaching material on access to gaining speaking skills in English language teaching] Unpublished Master Thesis, Hacettepe University, Ankara. 
Fenson, L., Dale, P. S., Reznick, J. S., Bates, E., Thal, D. \& Pethick, S. (1994). Variability in early communicative development. Monographs of the Society for Research in Child Development, 59(5), 174-185.

Fromkin, V., Rodman, R. \& Hyams, N. (2011). An introduction to language (9th ed.). Cengage Learning.

Fromkin, V. \& Rodman, R. (1983). An introduction to language (3rd ed.). Holt, Rinehart and Winston.

Gordon, P. A. \& Luper, H. L. (1989). Speech disfluencies in nonstutterers: Syntactic complexity and production task effects. Journal of Fluency Disorders, 14(6), 429-445.

Goswami, U. \& Bryant, P. (1990). Phonological skills and learning to read. Hillsdale: Lawrence Erlbaum.

Guitar, B. (2013). Stuttering: An integrated approach to its nature and treatment (4th Ed.). Lippincott, William \& Wilkins.

Hirsch, E. D. (2006). Building knowledge: The case for bringing content into the language arts block and for knowledge-rich curriculum core for all children. American Educator, 30(1), $8-18$.

Hoff, E. (2009). Language Development (4th ed.). Cengage Learning.

Hoien, T., Lundberg, I., Stanovich, K. \& Bjaalid, I. (1995). Components of phonological awareness. Reading and Writing, 7, 171-188.

İpek, N. (2006). İlköğretim çă̆ı çocuklarında kelime dağarcı̆̆ı gelişimi [Vocabulary development in primary school children] Unpublished Master Thesis, Uludag University, Bursa.

Karasar, N. (2000). Bilimsel Araştırma Yöntemi [Scientific research method]. (10. Bask1). Nobel Yayın Dağıtım.

Keçik, İ. \& Uzun-Subaş1, L. (2003). Sözlü ve yazılı anlatım üzerine [On verbal and written expression] (Ed. Canan İleri), Türkçe Sözlü ve Yazılı Anlatım içinde, Anadolu Üniversitesi Yayınlar1.

Kieffer, M. \& Lesaux, N. K. (2012). Knowledge of words, knowledge about words: Dimensions of vocabulary in first and second language learners in sixth grade. Reading and Writing: An Interdisciplinary Journal, 25(2), 347-373.

Kirjavainen, M., Theakston, A., Lieven, E. \& Tomasello, M. (2009). I want hold Postman Pat': an investigation into the acquisition of infinitival marker 'to'. First Language, 29, 313-339.

Koçak, N. \& Dereli, Esra. (2005). Okul öncesi eğitime devam eden 4-6 yaş arasındaki çocukların ifade edici dil düzeylerinin bakım tarzı ve anne- baba eğitim düzeyi açısından incelenmesi [Examining the expressive language levels of children between the ages of 4-6 who attend pre-school education in terms of care style and 128 education level of parents]. Sosyal Bilimler Enstitüsü Dergisi, 14, 245-253.

Kuru, O. (2013). Akıcı konuşma problemi yaşayan ilköğretim 5. sınıf öğrencisinin konuşma becerisini geliştirme [Improving the speaking skills of elementary school 5th grade students who have fluency problems]. Uluslararası Türk Eğitim Bilimleri Dergisi, 1(1), 88-105.

Kurudayığlu, M. (2003). Konuşma eğitimi ve konuşma becerisini geliştirmeye yönelik etkinlikler [Speaking education and activities to improve speaking skills]. Türklük Bilimi Araştırmaları, Türkçenin Öğretimi Özel Sayısı, 13, 267-309.

Lee, Y. J., Lee, G. G. \& Oh, H. N. (2013). An exploratory study on young children's spoken and written narratives of personal experience. Asia-Pacific Journal of Research in Early Childhood Education, 7(2), 47-61. 
Levelt, W. J. M. (1989). Speaking: From intention to articulation. M.I.T. Press.

Lundberg, I., Frost, J. \& Peterson, O.-P. (1988). Effects of an extensive program for stimulating phonological awareness in preschool children. Reading Research Quarterly, 33, 263-284.

Lust, B. (2006). Child Language: Acquisition and Growth. Cambridge University Press.

Mercer, N. \& Littleton, N. (2007). Dialogue and the development of children's thinking: A sociocultural approach. Routledge.

O'Grady, W. (2008). How Children Learn Language (5th ed.). Cambridge University Press.

Owens, R. (2012). Language development: An introduction (8th ed.). Pearson.

Özbay, M. (2005). Sesle ilgili kavramlar ve konuşma [Sound concepts and speech]. Milli Eğitim Dergisi, 168, 116-125.

Özcan, F. H. (1993). Coherence in narratives of Turkish-speaking children. (Unpublished doctoral dissertation). University of Reading.

Öztürk, H. (1995). Okulöncesi eğitim kurumlarına giden ve gitmeyen ilkokul birinci sinıf ögrencilerinin alıcl ve ifade edici dil düzeyleri. [Receptive and expressive language levels of primary school first grade students who go to preschool education institutions and who do not] Unpublished Master Thesis, Gazi University, Ankara.

Perfetti, C. (2009). Decoding, vocabulary, and comprehension. In M. McKeown \& L. Kucan (Eds.), Bringing reading research to life (pp. 291-303). Guilford Press.

Resnick, L. B. \& Snow, C. E. (2009). Speaking and listening for preschool through third grade. International Reading Association.

Richards, J. C. (2006). Communicative language teaching today. Cambridge University Press.

Rowe, M.L., Raudenbush, S.W. \& Goldin-Meadow, S. (2012). The pace of vocabulary growth helps predict later vocabulary skill. Child Development, 83 (2), 508-525.

Scarborough, H. S. (2001). Connecting early language and literacy to later reading (dis)abilities: Evidence, theory, and practice. In S. B. Neuman \& D. K. Dickinson (Eds.), Handbook of early literacy research (pp. 97-110). Guilford Press.

Segalowitz, N. (2010). Cognitive bases of second language fluency. Routledge.

Silverman, R. (2007). A comparison of three methods of vocabulary instruction during read-alouds in kindergarten. Elementary School Journal, 108(2), 97-113.

Stanovich, K. (1992). Speculations on the causes and consequences of the individual differences in early reading acquisition. In P. Gough, L. Ehri and R. Treiman (eds), Reading Acquisition. Hillsdale: Lawrence Erlbaum.

Tabachnick, B. G. \& Fidell, L. S. (2013). Using multivariate statistics (6th ed.), Allyn and Bacon.

Taner, M. (2003). Okul öncesi eğitimi alan ve almayan farkl sosyo-ekonomik düzeylerdeki ilköğretim birinci sınıf öğrencilerinin dil gelişimlerinin karşılaştırılması [Comparison of the language development of primary school first grade students at different socioeconomic levels who received pre-school education and who did not]. Unpublished Master Thesis, Uludag University, Bursa.

Topbaş, S. (2010). Sesbilgisel Gelişim [Phonological Development] (Editör: S. Seyhun Topbaş). Dil ve Kavram Gelişimi. Kök Yayıncılık.

Treiman, R. \& Zukowski, A. (1991). Levels of phonological awareness. In S. Brady and D. Shankweiler (eds), Phonological Processes in Literacy. Hillsdale: Lawrence Erlbaum.

Tural, A. (1977). Ankara'da anaokuluna giden ve gitmeyen 4-6 yaş çocuklarının bildikleri kelime saylsına yaş, cinsiyet, ailenin eğitim düzeyi ve okula devam süresinin etkisi [The effect of age, gender, education level of the family and duration of school attendance on the number 
of words known by 4-6 year old children who go to kindergarten and not]. Unpublished Master Thesis, Hacettepe University, Ankara.

Van Dam, F. J. (2010). Development of cohesion in normal children's narratives (Research Report). Utrecht: University of Utrecht. http://dspace.library.uu.nl/handle/1874/180044

Van Kleeck, A. (2008). Providing preschool foundations for later reading comprehension: The importance of and ideas for targeting inferencing in storybook-sharing interventions. Psychology in the Schools, 45, 627-643.

Vagh, S.B., Pan, B. A. \& Mancilla-Martinez, J. (2009). Measuring growth in bilingual and monolingual children's English productive vocabulary development: The utility of combining parent and teacher report. Child Development, 80 (5), 1545-1563.

Wells, G. (1999). Dialogic inquiry: Towards a sociocultural practice and theory of education. Cambridge University Press. 